Research Paper

\title{
CC16-TNF- $\alpha$ negative feedback loop formed between Clara cells and normal airway epithelial cells protects against diesel exhaust particles exposure-induced inflammation
}

\author{
Ting $\mathrm{Hu}^{1}$, Fenglan Sun ${ }^{1}$, Xinjuan $\mathrm{Yu}^{1}$, Qinghai $\mathrm{Li}^{1}$, Long $\mathrm{Zhao}^{1}$, Wanming $\mathrm{Hao}^{1, \&}$, Wei $\mathrm{Han}^{1}$ \\ ${ }^{1}$ Qingdao Municipal Hospital, School of Medicine, Qingdao University, Qingdao 266011, China
}

Correspondence to: Wanming Hao, Wei Han; email: wmhao@yandex.com, hanw@qdu.edu.cn

Keywords: diesel exhaust particles, clara cell secretory protein, C/EBP $\alpha$, Munc18b, TNF- $\alpha$

Received: February 3, $2021 \quad$ Accepted: July 8, $2021 \quad$ Published: August 2, 2021

Copyright: (C) $2021 \mathrm{Hu}$ et al. This is an open access article distributed under the terms of the Creative Commons Attribution License (CC BY 3.0), which permits unrestricted use, distribution, and reproduction in any medium, provided the original author and source are credited.

\section{ABSTRACT}

CC16 is almost exclusively expressed in non-ciliated epithelial Clara cells, and widely used as a Clara cell marker. Diesel exhaust particles (DEPs), the fine particulate matters produced by diesel engines, cause or exacerbate airway-related diseases. Our previous study documented that DEP inhibits the CC16 expression in the immortalized mouse Clara cell line through methylation of C/EBP $\alpha$ promoter. However, the molecular mechanism by which DEP regulates CC16 secretion is unclear. Here, we isolated CC16 containing Clara cells $\left(\mathrm{CC}^{+}{ }^{+}\right)$from human distal lung, and found that DEP inhibited CC16 secretion from $\mathrm{CC}^{16}{ }^{+}$cells via methylation of $\mathrm{C} / \mathrm{EBP} \alpha$ and inhibition of Munc18b transcription. $\mathrm{CC}^{+} 6^{+}$cell conditioned media containing different concentrations of CC16 was prepared and used for culture of airway epithelial cells BEAS-2B with no expression of CC16. A positive correlation was observed between CC16 level and DEP-induced autophagy activity, and a negative correlation between CC16 level and DEP-induced pro-inflammatory cytokine TNF- $\alpha$, IL- 6 , and IL-8 level, suggesting that CC16 might mitigate DEP-induced inflammation via promoting autophagy in BEAS-2B cells. This result was further confirmed by adding recombinant CC16 to BEAS-2B cells exposed to DEP. Moreover, CC16 level was significantly increased when $\mathrm{CC}^{+} 6^{+}$cells were cultured in BEAS-2B cell conditioned medium containing TNF- $\alpha$ or the normal medium supplemented with recombinant TNF- $\alpha$, suggesting that TNF- $\alpha$ induced CC16 production and secretion from $\mathrm{CC}^{+}{ }^{+}$cells. Collectively, these data point that CC16 and TNF- $\alpha$ form a negative feedback loop, and this negative feedback loop between Clara cells and normal airway epithelial cells protects against DEP exposure-induced inflammation.

\section{INTRODUCTION}

Accumulating epidemiological, laboratory and clinical studies demonstrate that exposure to increased level of particulate matter $(\mathrm{PM})$ is related to the increased morbidity and mortality of multiple human diseases, such as allergic disorders, respiratory diseases, cardiac diseases, and renal diseases [1-4]. In recent years, PM2.5, less than $2.5 \mu \mathrm{m}$ in diameter, has received significant attention. Due to the small size, PM2.5 is able to reach alveolar spaces, and precipitates throughout the whole lung, including the periphery, thereby triggering the biological responses and eliciting diseases $[5,6]$.

With the development of the economy, logistics based on the transportation industry has become a major service industry in the modern national economy. In the transport industry, diesel engines are predominantly used due to high efficiency and low cost. Diesel exhaust particles (DEPs), the fine particulate matters produced by diesel engines, are one of the major parts of PM2.5. There is growing evidence that DEPs induce or exacerbate the diseases involving the airway, such as 
pulmonary arterial hypertension, asthma, and chronic obstructive pulmonary disease (COPD) [7-9].

Our previous in vivo and in vitro experiments also proposed that DEP exposure may impair lung function through inhibiting of $\mathrm{CC} 16$ expression by methylation of the $\mathrm{C} / \mathrm{EBP} \alpha$ promoter [10]. CC16, a secretory protein, functions after secretion from cells. However, the molecular mechanism by which DEP regulates the secretion of CC16 is uncertain. Munc18b is a limiting component of the exocytic machinery of the secretory epithelia and immune cells. Our previous study displayed that Munc18b knockdown significantly inhibited the MUC5AC secretion from bronchial epithelial cells $[11,12]$. C/EBP $\alpha$, a transcription factor, regulates the expression of multiple genes by binding to the promoter. By searching the Jaspar database, we found that the potential binding motifs exist between $\mathrm{C} / \mathrm{EBP} \alpha$ and the Munc18b promoter region in different species (human, rat and mouse). Given these findings, we further explored whether $\mathrm{C} / \mathrm{EBP} \alpha$ promotes $\mathrm{CC} 16$ secretion via regulation of Munc18b expression.

CC16, specifically expressed in distal airway Clara cells, is the most abundant secretory protein in the airway surface fluid, accounting for $5 \%$ of the total protein quantity recovered by bronchoalveolar lavage [13]. It is well known that CC16 has anti-inflammatory and antioxidant effects [14-19]. The change in CC16 level not only has a profound effect on the composition of the airway surface fluid, but also affects the response of the airway epithelium to environmental stimuli [2022]. For instance, CC16 mitigates house dust miteinduced airway inflammation and damage via regulation of airway epithelial cell apoptosis [20]; and CC16 level is also correlated with cigarette smoke exposure in bronchial epithelial cells, and protects against lung injury in smokers [21]. It has been widely reported that DEP causes a pro-inflammatory response in bronchial epithelial cells [23-25]. However, the role of CC16 in bronchial epithelial cells exposed to DEP has not been reported. We speculated that $\mathrm{CC} 16$ protects against bronchial epithelial cell inflammation, and the lower CC16 secretion level from Clara cells caused by DEP exposure exerts the weaker protective effects in DEPinduced bronchial epithelial cell inflammation.

Additionally, TNF- $\alpha$ has been reported to drive CC16 production [26]. Given these findings, it was tempting to speculate that DEP-induced TNF- $\alpha$ increase in bronchial epithelial cells stimulates $\mathrm{CC} 16$ production by Clara cells, and CC16 and TNF- $\alpha$ form a negative feedback, thereby inhibiting DEP exposure-induced injury.

Herein, we aimed to investigate whether DEP inhibits CC16 secretion from Clara cells via C/EBP $\alpha$-Munc18b axis, and CC16 and TNF- $\alpha$ form a negative feedback against DEP-induced bronchial epithelial cell inflammation.

\section{RESULTS}

\section{Characterization of the sorted cells}

Single cell suspensions were prepared by human distant normal lung tissues where Clara cells are located, and $\mathrm{CC} 6^{+}$and $\mathrm{CC}^{-} 6^{-}$cells were sorted directly by Fluorescence-activated cell sorting (FACS). The sorted $\mathrm{CC} 6^{+}$and $\mathrm{CC} 16^{-}$cells were cultured overnight, and unattached dead cells were removed from the medium. The CC16 mRNA and protein expression were subsequently detected. As shown in Figure 1A, 1B, CC16 mRNA and protein expression were sharply higher in $\mathrm{CC} 6^{+}$cell fraction than in $\mathrm{CC}^{-} 6^{-}$cells. We also performed immunocytochemistry staining of $\mathrm{CC} 16$ in sorted cells. As evidence by Figure 1C, 98\% of the cells in $\mathrm{CC}_{16}{ }^{+}$sorted fraction were positive for $\mathrm{CC} 16$ immunofluorescence (IF). In addition, to further confirm that the sorted $\mathrm{CC} 16^{+}$cells were distal airway Clara cells, the IF was performed for detection of pankeratin expression, the epithelial marker. The results showed that all cells in the $\mathrm{CC}_{16} 6^{+}$sorted fraction expressed pan-keratin (Figure 1D). These data suggested that CC16-containing Clara cells are successfully isolated.

\section{DEP exposure induces C/EBPA hypermethylation and decreases $\mathrm{CC16}$ production and secretion from $\mathrm{CC16}^{+}$cells}

Our previous study showed that in C22 cells, DEP decreases CC16 expression by methylation of the $\mathrm{C} / \mathrm{EBP} \alpha$ promoter [10]. But it is unknown whether DEP regulates $\mathrm{CC} 16$ secretion via $\mathrm{C} / \mathrm{EBP} \alpha$ hypermethylation. The level of $\mathrm{CC} 16$ protein released into the culture media represents CC16 secretion capacity. The $\mathrm{CC} 16^{+}$cells were exposed to $5 \mathrm{ppm}$ SRM $1650 \mathrm{~b}$ (the commercial DEP matter) in the presence of demethylating agent 5-aza-2'-deoxycytidine (DAC) or not for $48 \mathrm{~h}$. Then cells and culture supernatants were collected for methylation-specific polymerase chain reaction (MSP), RT-PCR, western blot and ELISA detection. The results of MSP determination showed that DEP treatment induced $\mathrm{C} / \mathrm{EBP} \alpha$ promoter methylation, while DAC treatment restored $\mathrm{C} / \mathrm{EBP} \alpha$ expression by demethylation of the promoter (Figure 2A). The results of RT-PCR and western blot showed that $\mathrm{DEP}$ treatment decreased $\mathrm{C} / \mathrm{EBP} \alpha$ mRNA and protein expression, which was significantly alleviated by DAC treatment (Figure 2B, 2C). Changes in CC16 level were consistent with changes in $\mathrm{C} / \mathrm{EBP} \alpha$ expression: DEP treatment significantly inhibited CC16 
A

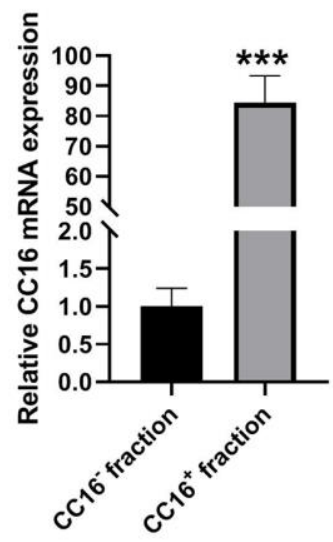

C
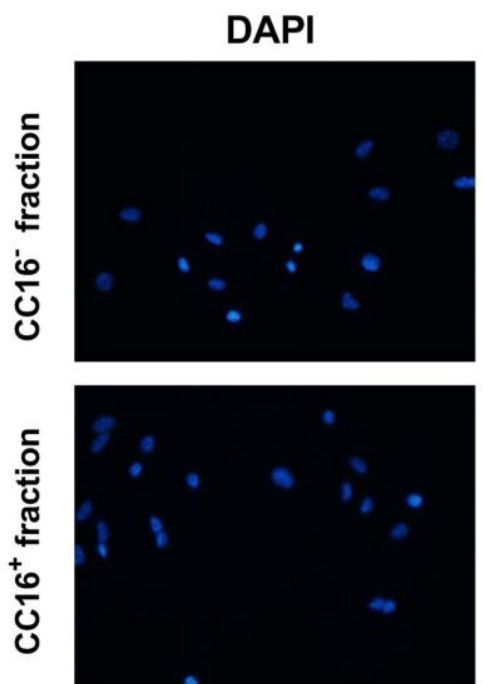

D
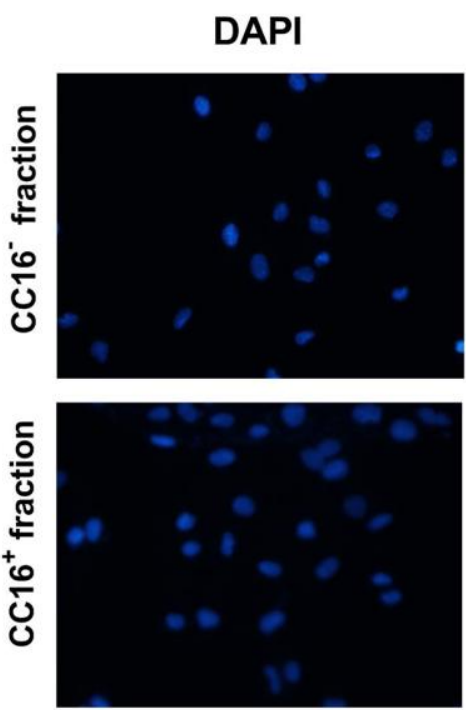

B
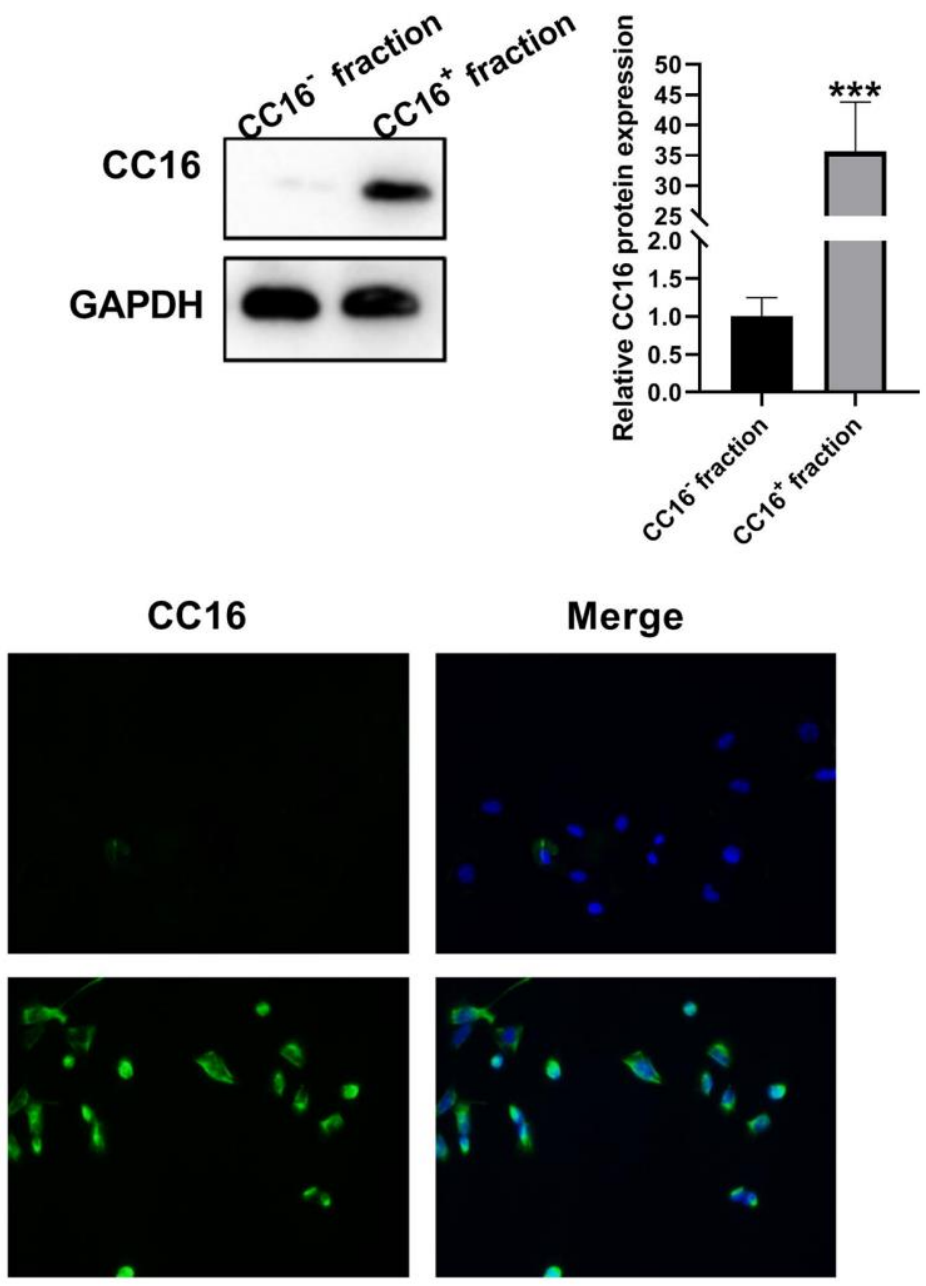

pan-keratin
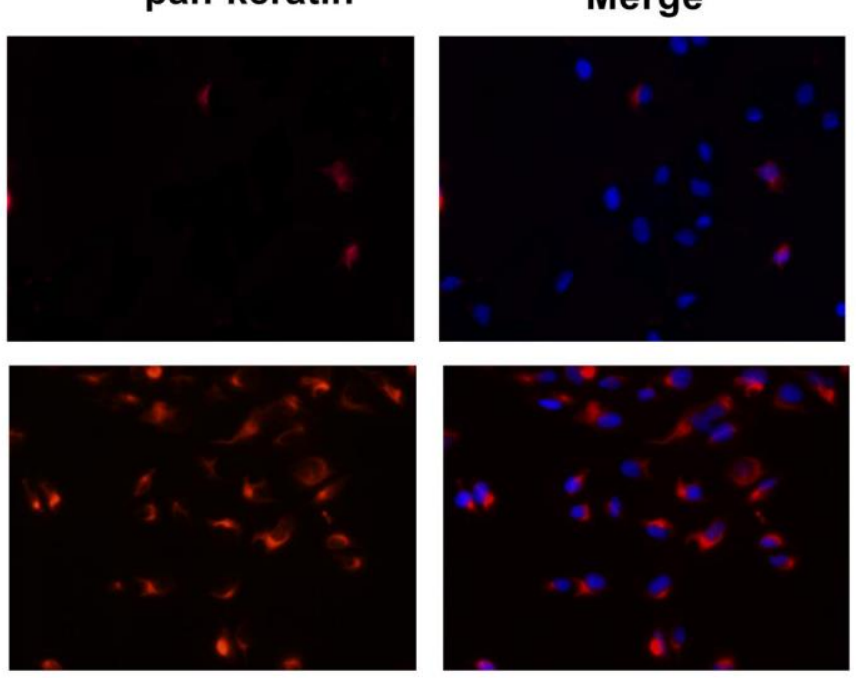

Figure 1. Characterization of sorted cells. (A, B) CC16 mRNA and protein expression in the sorted CC16 ${ }^{+}$and $\mathrm{CC}^{-} 16^{-}$cell fraction are detected by RT-PCR and western blot assay. (C, D) Immunofluorescence (IF) staining shows that $98 \%$ of the cells in CC16 sorted fraction express $\mathrm{CC} 16$, and all the cells in $\mathrm{CC}_{16}{ }^{+}$sorted fraction show positive expression of pan-keratin, the epithelial marker $(\times 100) . * * * P<0.001$ vs. CC16 fraction. 
mRNA expression and level in culture supernatants, which were abolished by DAC treatment (Figure 2D, 2E). In addition, we also detected the effects of treatment with other concentrations of SRM 1650b (0.1, $1,3$ and $10 \mathrm{ppm})$ on $\mathrm{C} / \mathrm{EBP} \alpha$ mRNA and protein expression, and CC16 mRNA expression and level in culture supernatants. This can be seen in Figure $2 \mathrm{~F}-2 \mathrm{H}$ that a dose-dependent inhibition of $\mathrm{C} / \mathrm{EBP} \alpha$ and $\mathrm{CC} 16$ by DEP was observed in $\mathrm{CC} 16^{+}$cells. Collectively, DEP exposure induces $\mathrm{C} / \mathrm{EBP} \alpha$ hypermethylation and decreases $\mathrm{CC} 16$ production and secretion in $\mathrm{CC}^{+} 6^{+}$ cells.

\section{C/EBPA regulates $\mathrm{CC16}$ secretion via Munc18b in $\mathrm{CC16}^{+}$cells}

Our previous study demonstrated that in C22 cells, $\mathrm{C} / \mathrm{EBP} \alpha$ regulates $\mathrm{CC} 16$ expression [10]. Herein, we

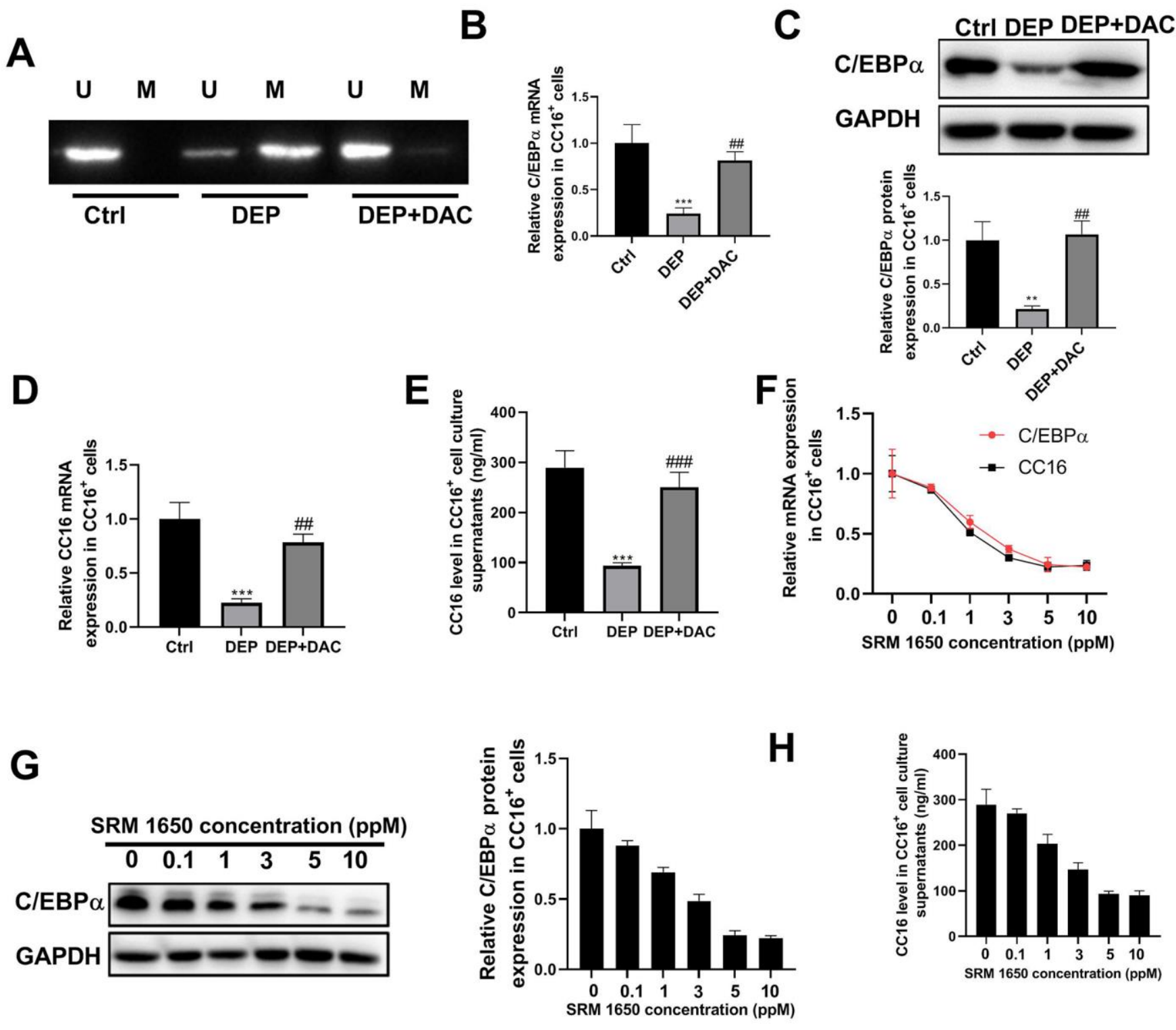

Figure 2. DEP exposure induces C/EBPa hypermethylation and decreases CC16 production and secretion in $\mathrm{CC}^{+}{ }^{+} \mathrm{Cells} \mathrm{CC} 6^{+}$ cells are exposed to 5 ppm SRM 1650b (the commercial DEP matter) in the presence of DAC or not for $48 \mathrm{~h}$, and then cells and culture supernatants are collected. (A) MSP analysis is performed to detect the methylation of C/EBPa promoter. Lane $U$, amplified product with primers recognizing unmethylated $\mathrm{C} / \mathrm{EBP} \alpha$ sequence. Lane $\mathrm{M}$, amplified product with primers recognizing methylated $\mathrm{C} / \mathrm{EBP} \alpha$ sequence. (B, C) The mRNA and protein expression of C/EBP $\alpha$ are determined by RT-PCR and western blot assay. (D, E) CC16 mRNA expression and level in culture supernatants are detected by RT-PCR and ELISA assay. (F-H) After treatment of $\mathrm{CC} 16^{+}$cells with different concentrations of SRM $1650 \mathrm{~b}(0.1,1,3,5$ and $10 \mathrm{ppM}), \mathrm{C} / \mathrm{EBP} \alpha$ and CC16 mRNA expression, C/EBP $\alpha$ protein expression, and CC16 level in culture supernatants are determined by RT-PCR, western blot and ELISA assay. ${ }^{* *} P<0.01$ and ${ }^{* * *} P<0.001$ vs. Ctrl group; ${ }^{\# \#} P<0.01$ and ${ }^{\# \#} P<0.001$ vs. DEP group. 
investigated whether and how $\mathrm{C} / \mathrm{EBP} \alpha$ regulates $\mathrm{CC} 16$ secretion. As shown in Figure 3A, 3B, C/EBP $\alpha$ overexpression caused the increases in CC16 mRNA and protein released into the culture medium, whereas $\mathrm{C} / \mathrm{EBP} \alpha$ knockdown resulted in the decreases of $\mathrm{CC} 16$ mRNA and secretion.
Munc18b is a limiting component of the exocytic machinery of secretory epithelial and immune cells. By searching the Jaspar database, we found that the $2-\mathrm{kb}$ region upstream of Munc18b gene contains potential binding motifs for transcription factor $\mathrm{C} / \mathrm{EBP} \alpha$ in different species (human, rat and mouse) (Table 1). We
A

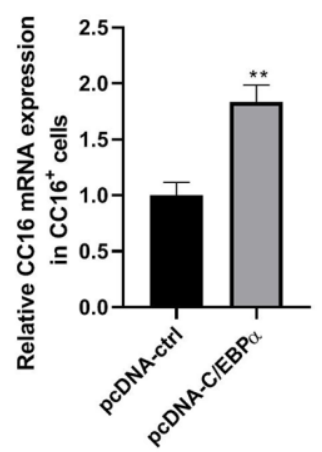

C

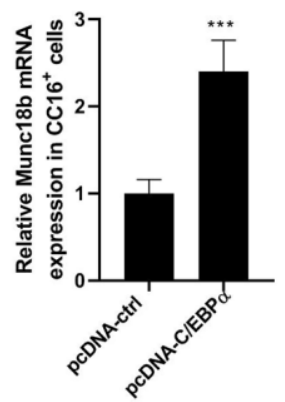

E

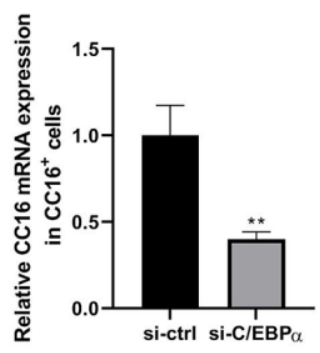

D
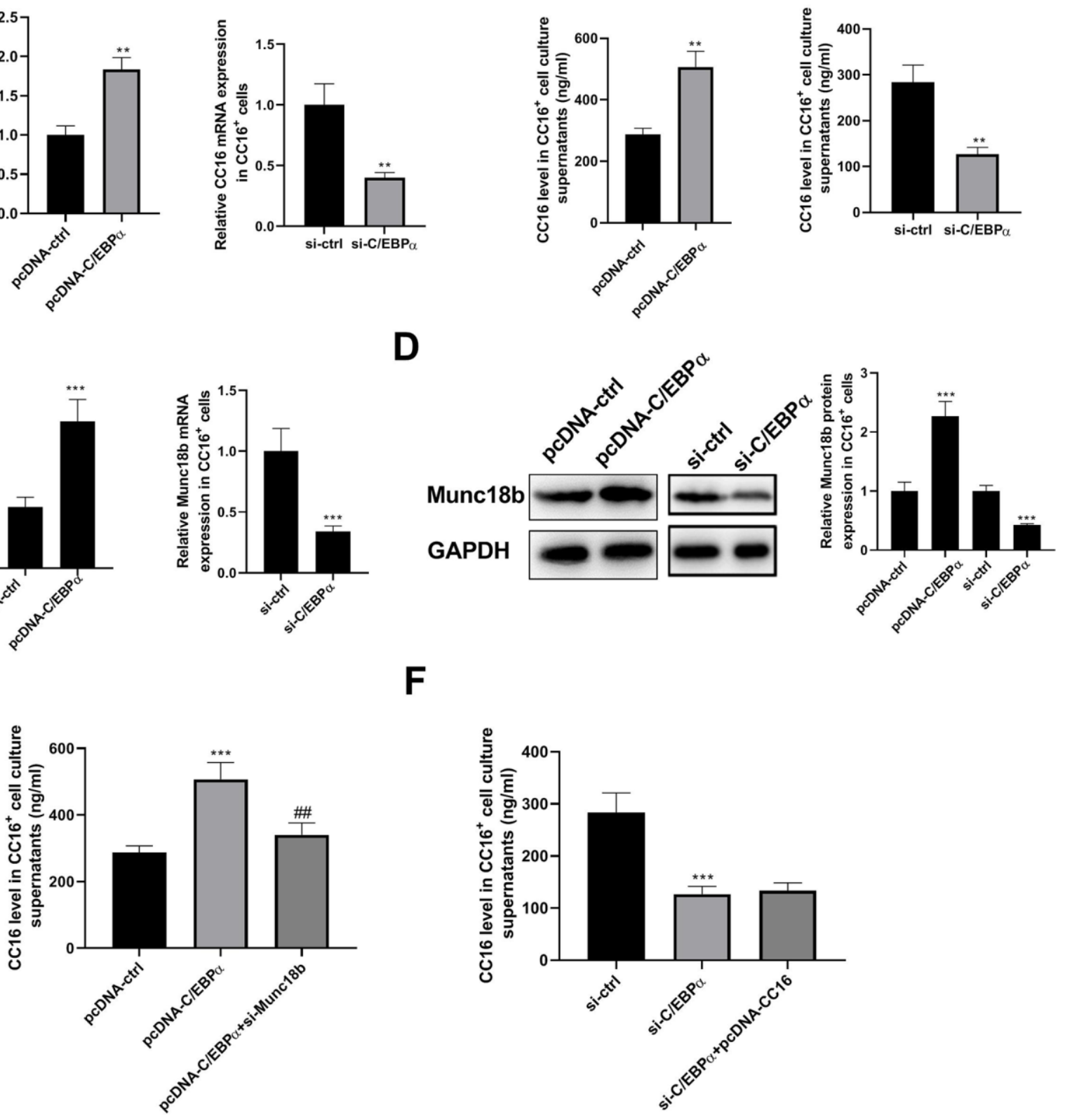

Figure 3. C/EBPa regulates CC16 secretion via Munc18b in $\mathrm{CC}{ }^{+}$cells. After transfection of $\mathrm{CC} 16^{+}$cells with pcDNA-ctrl, pcDNA$\mathrm{C} / \mathrm{EBP} \alpha, \mathrm{pcDNA}-\mathrm{C} / \mathrm{EBP} \alpha+\mathrm{si}-\mathrm{Munc} 18 \mathrm{~b}$, si-ctrl, si-C/EBP $\alpha$, or si-C/EBP $\alpha+$ pcDNA-CC16, cells are cultured for $48 \mathrm{~h}$, and then cells and culture supernatants are collected. (A, B) The effects of C/EBP $\alpha$ overexpression or knockdown on CC16 mRNA and protein released into the culture media are detected by RT-PCR and ELISA. (C, D) The effects of C/EBP $\alpha$ overexpression or knockdown on Munc18b mRNA and protein expression are detected by RT-PCR and western blot assay. (E, F) The increase of CC16 secretion induced by C/EBP $\alpha$ overexpression is abolished by Munc18b knockdown, while the decrease of CC16 secretion induced by C/EBP $\alpha$ knockdown is not affected by CC16 overexpression. ${ }^{* * P}<0.01$ and ${ }^{* * *} P<0.001$ vs. pcDNA-ctrl or si-ctrl group; ${ }^{\# \#} P<0.01$ vs. pcDNA-C/EBP $\alpha$ group. 
Table 1. The predicted binding sites between C/EBPa and the promoter region of Munc18b.

\begin{tabular}{llccccc}
\hline Species & Matrix ID & Name & Score & Start & End & Predicted sequence \\
\hline Human & MA0102.3 & CEBPA & 5.139 & -1715 & -1705 & gttacaaaagg \\
Human & MA0102.3 & CEBPA & 2.555 & -1415 & -1405 & tttacaaaaca \\
Rat & MA0019.1 & Cebpa & 10.074 & -1021 & -1010 & ggatgcaattgt \\
Mice & MA0102.1 & Cebpa & 8.717 & -274 & -263 & ttgcccaagctt \\
Mice & MA0102.1 & Cebpa & 6.675 & -361 & -350 & ttacagaatgtt \\
Mice & MA0102.1 & Cebpa & 6.335 & -792 & -781 & atgtacaacagg \\
\hline
\end{tabular}

thus examined whether $\mathrm{C} / \mathrm{EBP} \alpha$ regulates the transcription of Munc18b. As shown in Figure 3C, 3D, overexpression of $\mathrm{C} / \mathrm{EBP} \alpha$ significantly increased the expression of Munc18b mRNA and protein. As expected, knockdown of $\mathrm{C} / \mathrm{EBP} \alpha$ significantly reduced the expression of Munc18b mRNA and protein. In addition, the increase of $\mathrm{CC} 16$ secretion induced by $\mathrm{C} / \mathrm{EBP} \alpha$ overexpression was abolished by Munc18b knockdown, while the decrease of $\mathrm{CC} 16$ secretion induced by $\mathrm{C} / \mathrm{EBP} \alpha$ knockdown was not affected by CC16 overexpression (Figure 3E, 3F). These data suggested that $\mathrm{C} / \mathrm{EBP} \alpha$ promotes $\mathrm{CC} 16$ secretion through upregulation of Munc18b in $\mathrm{CC}^{+} 6^{+}$cells.

\section{C/EBPA can directly bind to the promoter region of Munc18b}

Given the above findings that the upstream of human Munc18b gene has two putative $\mathrm{C} / \mathrm{EBP} \alpha$ binding sites $(-1705$ and $-1405 \mathrm{bp})$, and $\mathrm{C} / \mathrm{EBP} \alpha$ promotes Munc18b expression at the transcriptional level, we performed dual-luciferase reporter assay and chromatin immunoprecipitation (ChIP) assay to further investigate whether $\mathrm{C} / \mathrm{EBP} \alpha$ activates Munc18b transcription by directly binding to its putative promoter region. The luciferase activity was detected in $\mathrm{CC}_{16}{ }^{+}$cells transfected with both Munc18b promoter construct (-2000/200; Munc18bpromS) or empty pGL3-basic vector (Munc18bvector) and $\mathrm{C} / \mathrm{EBP} \alpha$ plasmid or its corresponding empty vector for $48 \mathrm{~h}$. The results showed that Munc18b promoter construct led to an obvious increase in the relative luciferase activity, which was further reinforced by $\mathrm{C} / \mathrm{EBP} \alpha$ (Figure $4 \mathrm{~A})$. To identify the exact position where $\mathrm{C} / \mathrm{EBP} \alpha$ could bind within this fragment, a ChIP test was performed. As shown in Figure $4 \mathrm{~B}, \mathrm{C} / \mathrm{EBP} \alpha$ could bind to two putative binding sites, site 1 and site 2 sequences. Furthermore, to further clarify the function of site 1 and site 2, Munc18b promoter with wild-type (WT) or mutation of the binding motif 1 or 2 , and $\mathrm{C} / \mathrm{EBP} \alpha$ plasmid were co-transfected into $\mathrm{CC} 6^{+}$cells. The results of the dual-luciferase reporter assay showed that in comparison with WT group, mutation of the binding motif 1 significantly inhibited the relative luciferase activity, and mutation of the binding motif 2 had no effect on the relative luciferase activity, suggesting that the site 1 was a functional site controlling Munc18b transcription (Figure 4C). These results indicated that $\mathrm{C} / \mathrm{EBP} \alpha$ activates Munc18b transcription by direct binding to the sites -1715/1705 in Munc18b promoter.

\section{DEP induces bronchial epithelial cell autophagy and inflammation}

DEP has been widely reported to induce bronchial epithelial cell injury by regulation of autophagy, inflammation, oxidative stress, and apoptosis [27-30]. Here, we investigated the effects of DEP on autophagy and inflammation of BEAS-2B bronchial epithelial cells. LC3 and p62 are two proteins vital for autophagy. When autophagy is activated, soluble LC3-I is converted into lipid bound LC3-II, followed by being recruited to autophagosomal membranes, and thus the amount of LC3-II positively correlates with the number of autophagosomes. Furthermore, autophagosome formation enhances the autophagic flux, thereby accelerating p62 protein degradation. As evidenced by Figure 5A, DEP increased the ratio of LC3-II/LC3-I, and decreased p62 protein expression, which suggested that DEP treatment activated autophagy. DEP-activated autophagy was further reinforced by the autophagy promoter rapamycin (Rap), and relieved by the autophagy inhibitor 3-Methyladenine (3-MA). In addition, autophagosomes were identified as bright green dots by IF. The co-treatment group with Rap and DEP had the largest number of green spots, followed by DEP group, DEP+3-MA group, and ctrl group (Figure $5 B)$. The effects of DEP exposure on pro-inflammatory cytokines were also detected. The results indicated that DEP exposure increased TNF- $\alpha$, IL- 6 , and IL- 8 level, which were relieved by Rap treatment, and aggravated by 3-MA treatment (Figure 5C-5E). These data suggested that enhancing autophagy can mitigate DEPinduced inflammation in BEAS-2B cells. 
A

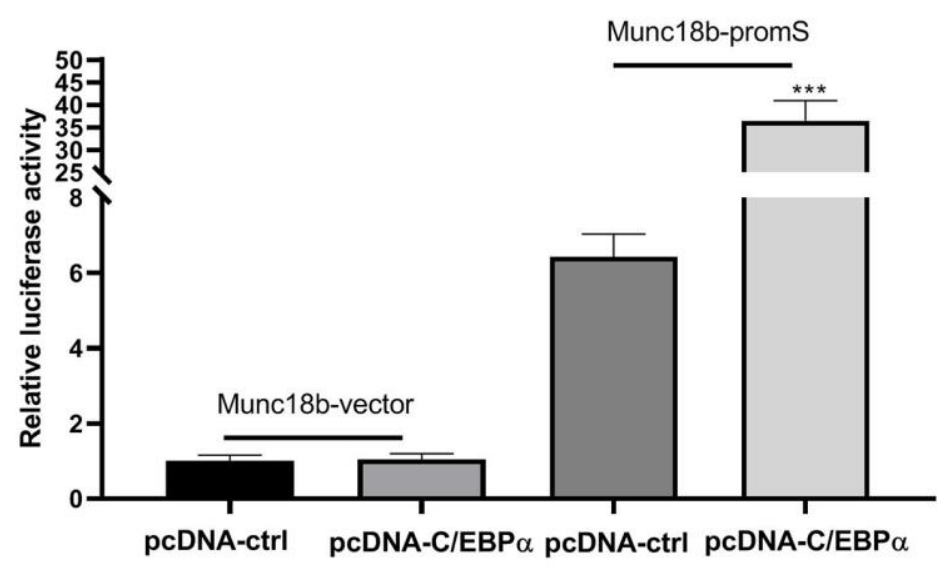

B

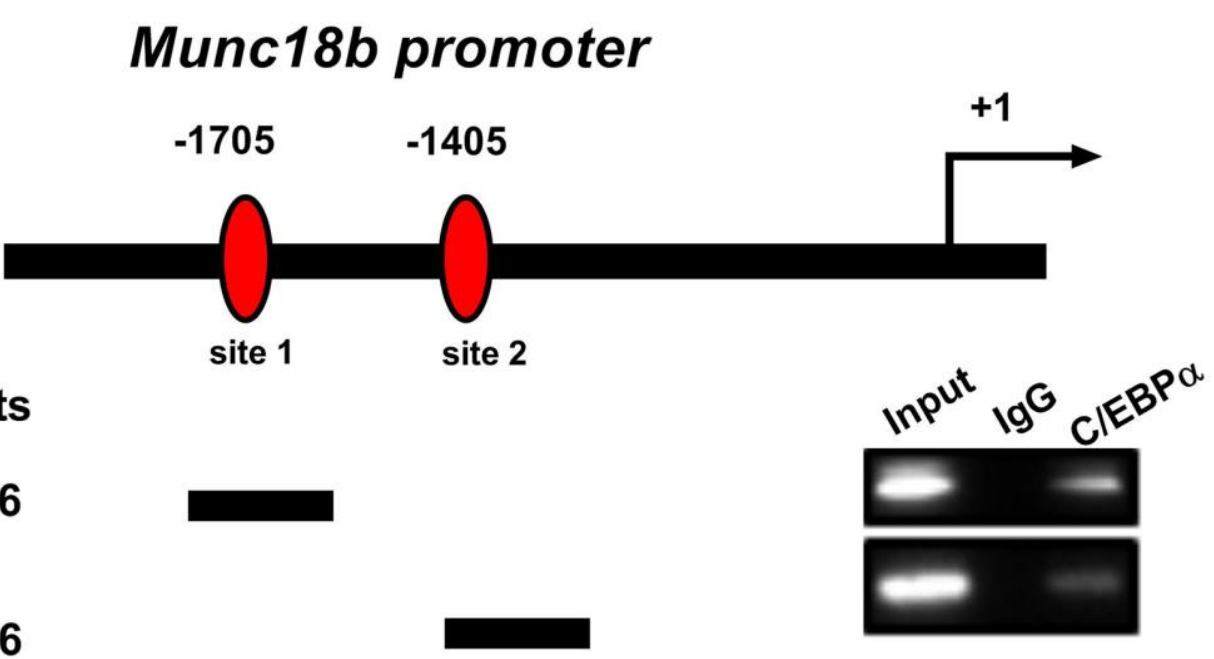

$-1555 /-1256$

C

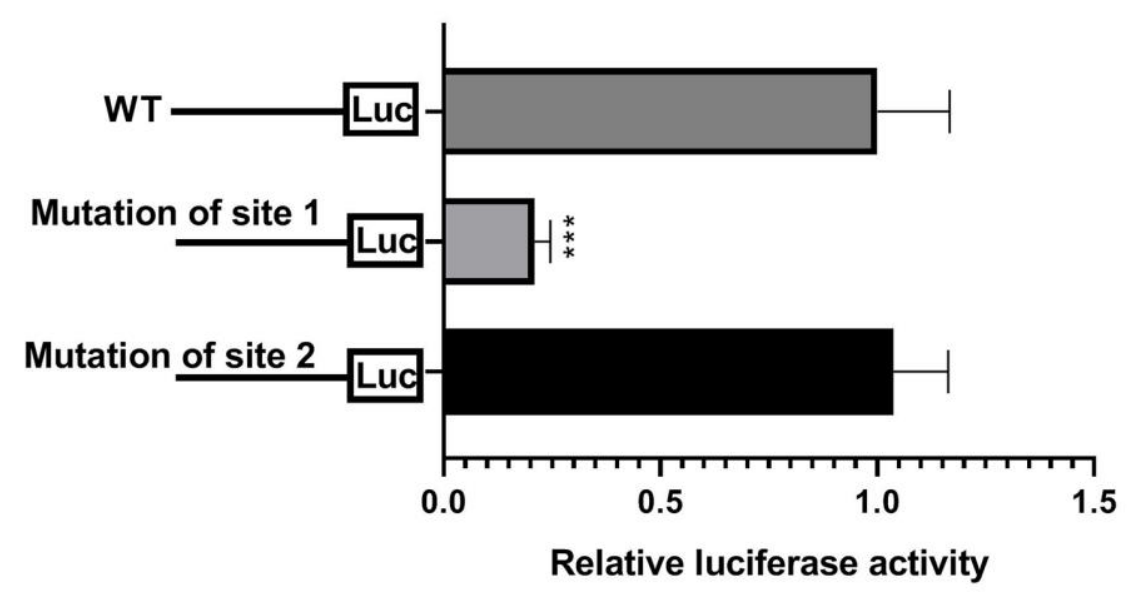

Figure 4. C/EBPa can directly bind to the promoter region of Munc18b. (A) $\mathrm{CC} 16^{+}$cells are transfected with both Munc18b promoter (-2000/200; Munc18b-promS) or empty pGL3-basic vector (Munc18b-vector) and C/EBP $\alpha$ plasmid or its corresponding empty vector control for $48 \mathrm{~h}$, and then the cells are collected for luciferase activity detection. (B) ChIP assay is conducted in CC16 ${ }^{+}$cells with the anti-C/EBP $\alpha$ antibody. Interaction sites are identified by PCR for two possible C/EBPa binding sites in the Munc18b promoter. (C) Munc18b promoter with wild-type (WT) or mutation of the binding motif 1 or 2, and C/EBPa plasmid are co-transfected into $\mathrm{CC} 16^{+}$cells used in the luciferase assay. ${ }^{* * *} P<0.001$ vs. pcDNA-ctrl or WT group. 


\section{A Ctrl DEP DEP+Rap DEP+3-MA}
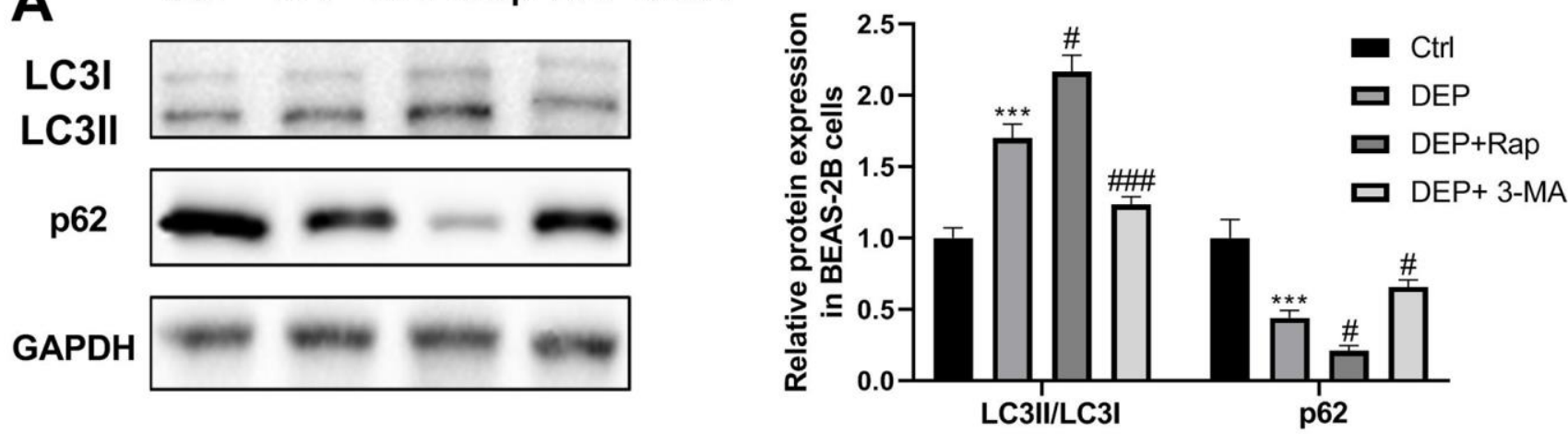

B

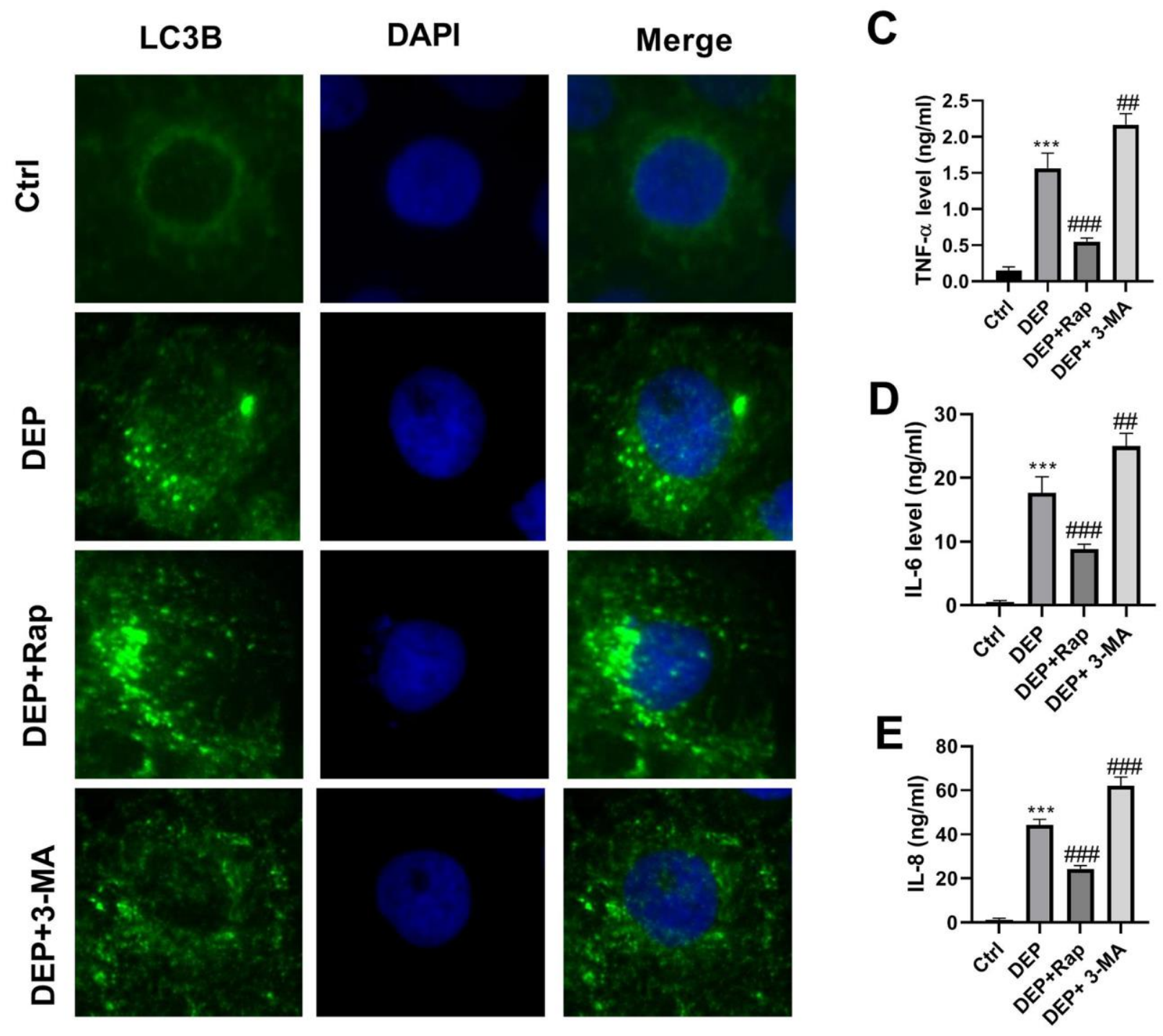

Figure 5. DEP induces bronchial epithelial cell autophagy and inflammation. BEAS-2B cells are pre-treated with $1.5 \mathrm{mM} 3-\mathrm{MA}$ or 10 $\mathrm{nM}$ Rap for $1 \mathrm{~h}$, and then exposed to 5 ppm SRM 1650b. After $12 \mathrm{~h}$, the cells and culture supernatants are collected. (A) Autophagy-related proteins LC3B and p62 expression in BEAS-2B cells are detected by western blot. (B) Autophagy induction is evaluated by LC3B immunostaining ( $\times$ 400). Autophagosomes are identified as bright green dots. (C-E) Pro-inflammatory cytokines TNF- $\alpha$, IL-6, and IL-8 level are detected by ELISA. ${ }^{* *} P<0.001$ vs. ctrl; ${ }^{\#} P<0.05$, $^{\# \#} P<0.01$, and ${ }^{\# \#} P<0.001$ vs. DEP group. 
CC16 secretion from $\mathrm{CC}^{+}$cells protects against DEP-induced bronchial epithelial cell inflammation

To investigate the effects of $\mathrm{CC} 16$ secretion from $\mathrm{CC} 6^{+}$cells on DEP-induced bronchial epithelial cell inflammation, $\mathrm{CC} 16+$ cells were cultured in DMEM/F12 medium with 5 ppm SRM 1650b or not to prepare $\mathrm{CC} 16^{+}$medium and DEP-CC $16^{+}$medium, respectively. After determining $\mathrm{CC} 16$ level, $\mathrm{CC}_{16}{ }^{+}$ cell conditioned medium were used to culture BEAS2B cells. The CC16 level within the medium of ctrl, $\mathrm{DEP}, \mathrm{DEP}+\mathrm{CC} 16^{+}, \mathrm{DEP}+\mathrm{DEP}-\mathrm{CC} 16^{+}$group was 0,0 , 144.7 and $46.5 \mathrm{ng} / \mathrm{ml}$, respectively. Following exposure to DEP, autophagy and inflammation were detected. As shown in Figure 6, $\mathrm{DEP}+\mathrm{CC} 16^{+}$group has the strongest autophagy activity, followed by DEP+DEP-CC $16^{+}$group, DEP group, and ctrl group. As expected, DEP induced the weakest inflammatory response in $\mathrm{DEP}+\mathrm{CC}_{16} 6^{+}$group, followed by DEP+DEP-CC16 ${ }^{+}$group, and DEP group. CC16 level was positively correlated with DEP-induced autophagy activity, and negatively correlated with DEPinduced inflammatory response, suggesting that $\mathrm{CC} 16$ might mitigate DEP-induced inflammation via promoting autophagy in BEAS-2B cells. In order to further confirm that $\mathrm{CC} 16^{+}$cell conditioned medium functions in DEP-induced autophagy and inflammation mainly through CC16, BEAS-2B cells were incubated with $5 \mathrm{ppm}$ SRM $1650 \mathrm{~b}$, or $300 \mathrm{ng} / \mathrm{ml}$ recombinant CC16 (rCC16)+5 ppm SRM 1650b for $12 \mathrm{~h}$. The results showed that rCC16 increased DEPinduced autophagy and inhibited DEP-induced inflammation (Figure 7). Collectively, these data indicated that $\mathrm{CC} 16$ protects against DEP-induced bronchial epithelial cell inflammation via regulation of autophagy, and DEP-inhibited CC16 secretion from Clara cells exerts a decreased protection role in DEP-induced bronchial epithelial cell inflammation.

\section{TNF- $\alpha$ released by BEAS-2B cells induces CC16 production and secretion in $\mathrm{CC}^{+} 6^{+}$cells}

TNF- $\alpha$ plays a role in stimulating CC16 production [26]. Herein, we investigated whether BEAS-2B cell conditioned medium stimulates $\mathrm{CC} 16$ production and secretion mainly via TNF- $\alpha$. As shown in Figure 8A, $8 \mathrm{~B}$, CC16 mRNA expression and level in culture supernatants were significantly increased when $\mathrm{CC} 6^{+}$ cells were cultured in BEAS-2B cell conditioned medium containing $0.81 \mathrm{ng} / \mathrm{ml} \mathrm{TNF-} \alpha$ or the normal medium supplemented with $3 \mathrm{ng} / \mathrm{ml}$ recombinant TNF$\alpha(\mathrm{rTNF}-\alpha)$. These data suggested that CC16 and TNF- $\alpha$ form a negative feedback loop: CC16 secreted by $\mathrm{CC} 6^{+}$cells inhibits TNF- $\alpha$ production in BEAS-2B cells, and TNF- $\alpha$ stimulates $\mathrm{CC} 16$ production and secretion, thereby protecting against DEP exposureinduced inflammation (Figure 8C).

\section{DISCUSSION}

CC16 belongs to the secretoglobin family, and is a small anti-inflammatory and antioxidant protein secreted by non-ciliated epithelial Clara cells. Respiratory diseases are often accompanied by varying degrees of damage in the structural integrity and function of airway epithelium, while CC16 is a useful biomarker of airway epithelial damages in chronic respiratory diseases. Increasing evidence has confirmed that the number of CC16-positive epithelial cells is significantly decreased in allergic airway diseases such as asthma, allergic rhinitis and chronic rhinosinusitis, resulting in the lower level of CC16 in airway mucosa and bronchoalveolar lavage fluid (BALF) [31]. The baseline serum CC16 level is believed to be a predictive biomarker of lung function, which is decreased in COPD patients and is also correlated with smoking status $[32,33]$. Another study documented that CC16deficient mice have more severe airway inflammation than wild-type mice [34, 35]. In addition, the CC16 level in BALF is lower in the silicosis group than the control group and may have a specific reference value for the early diagnosis of silicosis [36, 37]. Our previous study also showed that $\mathrm{CC} 16$ level is decreased in serum and BALF in mice with DEP exposure-induced lung injury. How does DEP exposure reduce $\mathrm{CC} 16$ level? Our previous study only confirmed that DEP inhibits $\mathrm{CC} 16$ expression in $\mathrm{C} 22$ cells by methylation of the $\mathrm{C} / \mathrm{EBP} \alpha$ promoter [10]. In fact, $\mathrm{CC} 16$, a secretory protein, works after release into extracellular environment (also called secretion), such as the airway surface fluid and the culture media. However, the molecular mechanism by which DEP regulates $\mathrm{CC} 16$ secretion is not clear.

In this study, we firstly isolated CC16-containing Clara cells from human distal lung by a flow cytometric sorting method, followed by investigating the effects of $\mathrm{DEP}$ exposure on $\mathrm{C} / \mathrm{EBP} \alpha$ methylation, and $\mathrm{CC} 16$ production and secretion. Consistent with our previous study, DEP exposure induces $\mathrm{C} / \mathrm{EBP} \alpha$ hypermethylation, and decreases $\mathrm{CC} 16$ production and secretion from $\mathrm{CC} 6^{+}$Cells [10]. Notably, further exploration of the mechanism displayed that $\mathrm{C} / \mathrm{EBP} \alpha$ promotes CC16 secretion via activation of Munc18b transcription by direct binding to the sites $-1715 /-1705$ in the Munc18b promoter.

Airway epithelial cells with an extremely low or no expression of $\mathrm{CC} 16$ represent most of the total epithelial cells. How does DEP affect these cells? The BEAS-2B cell line is a type of human airway epithelial cells. It has 
A

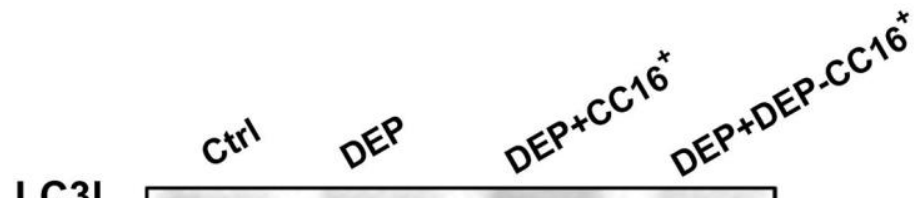

p62

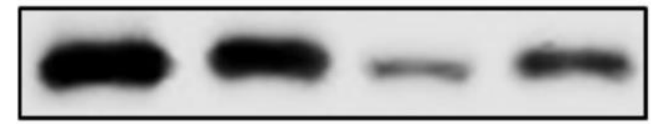

GAPDH
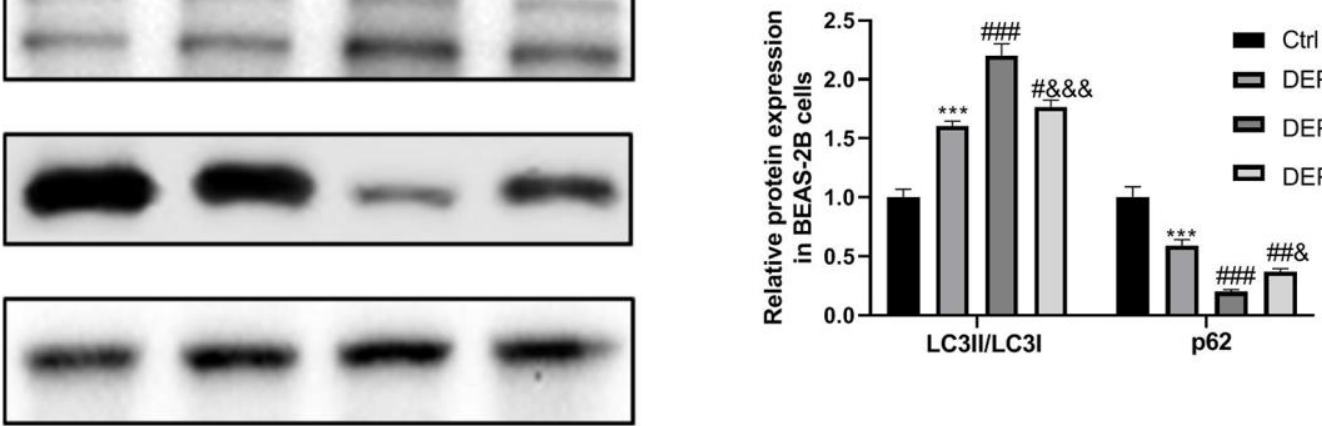

B
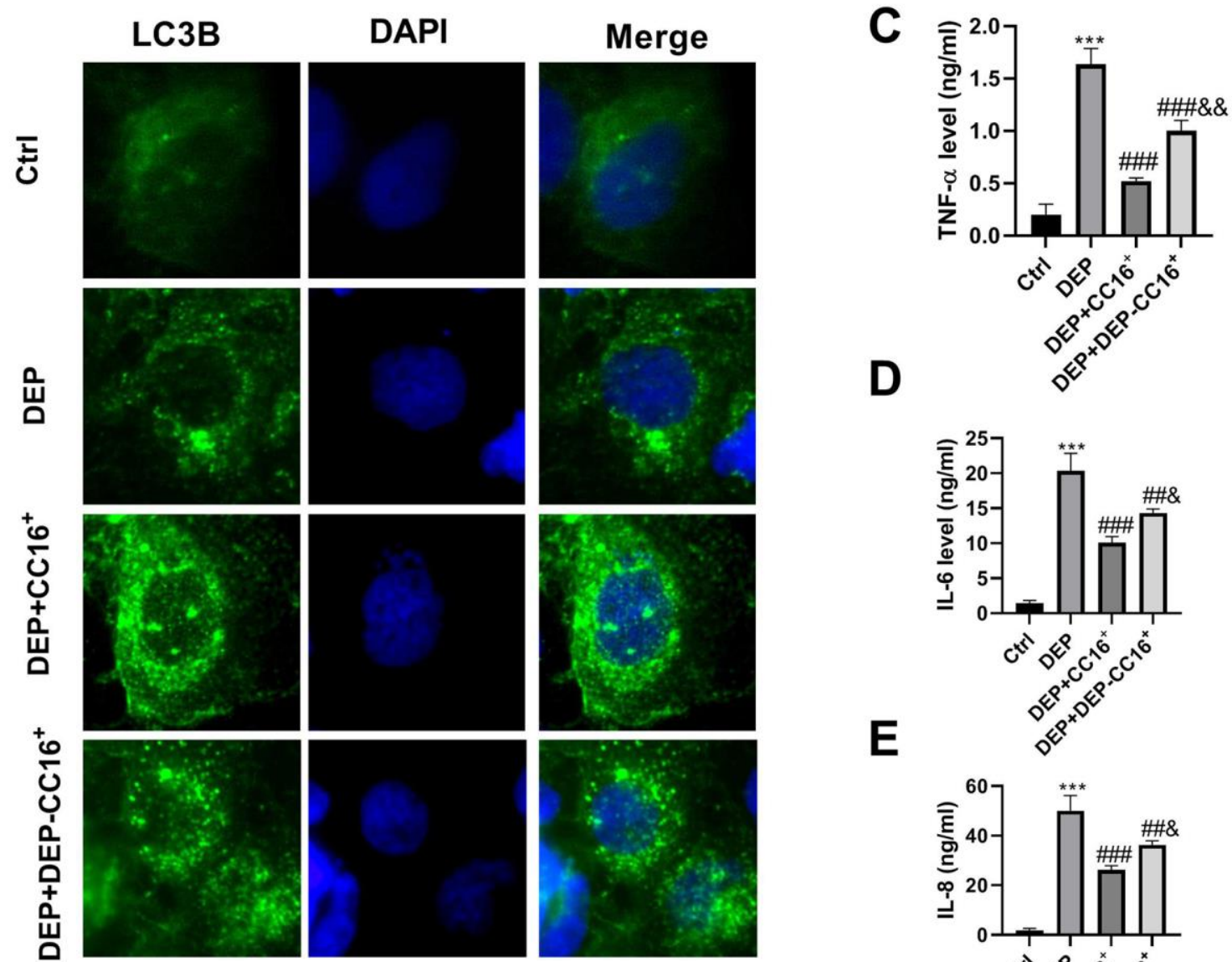

D

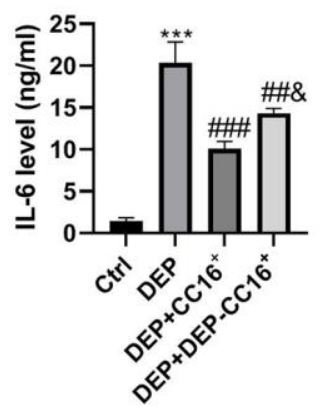

$\mathbf{E}$

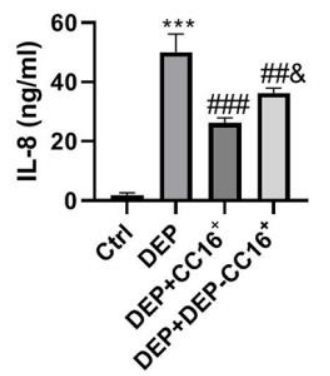

Figure 6. $\mathrm{CC} 16$ secretion from $\mathrm{CC}^{+}{ }^{+}$cells protects against DEP-induced bronchial epithelial cell inflammation via activation of autophagy. $\mathrm{CC} 6^{+}$cell conditioned medium containing different concentrations of $\mathrm{CC} 16$ is prepared, and used to culture BEAS-2B cells. The CC16 level in the medium of Ctrl, DEP, DEP+ CC16 ${ }^{+}$DEP+ DEP-CC16 ${ }^{+}$group is $0,0,144.7$ and $46.5 \mathrm{ng} / \mathrm{ml}$, respectively. After $12 \mathrm{~h}$ of culture, the cells and culture supernatants are collected. (A) LC3B and p62 protein expression in BEAS-2B cells are detected by western blot. (B) Autophagy induction is evaluated by LC3B immunostaining $(\times 400)$. Autophagosomes are identified as bright green dots. (C-E) TNF- $\alpha$, IL- 6 , and IL-8 level in culture supernatants are detected by ELISA. ${ }^{* * *} P<0.001$ vs. ctrl; ${ }^{\#} P<0.05,{ }^{\# \#} P<0.01$, and ${ }^{\# \#} P<0.001$ vs. DEP group; and ${ }^{\circledR} P$ $<0.05,{ }^{\text {\&\& }} P<0.01$, and ${ }^{\text {\&\&\& }} P<0.001$ vs. DEP+CC16 ${ }^{+}$group. 
been reported that $\mathrm{CC} 16$ could not be detected in BEAS-2B cell lysates [38]. We also examined CC16 protein content in BEAS-2B cells and culture supernatants. Consist with the findings of Mark and colleagues [38], CC16 is not detected in BEAS-2B cells and culture supernatants (data not shown). As such, BEAS-2B cells were chosen and used for investigating the effects of DEP on airway epithelial cells with no CC16 expression.
Indeed, two decades ago, studies suggested that DEP induces pro-inflammatory responses in BEAS-2B cells. For example, in 1999, Takizawa et al. [23] reported that DEP induces pro-inflammatory cytokine transcription through NF- $\kappa \mathrm{B}$ activation in BEAS-2B cells. Subsequently, Tal et al. [24] confirmed that low organic-containing DEP exposure stimulates proinflammatory cytokine IL-8 expression via activation of NF- $\kappa B-d e p e n d e n t$ of transcription. But high organic-
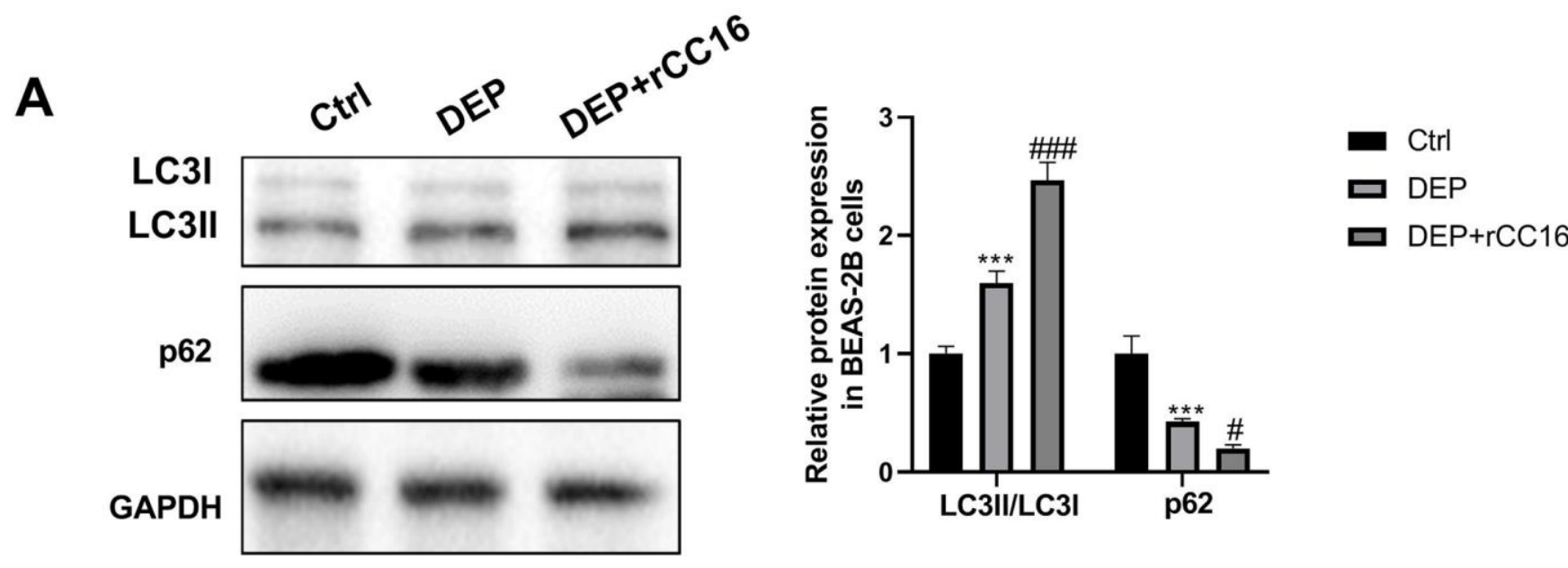

B

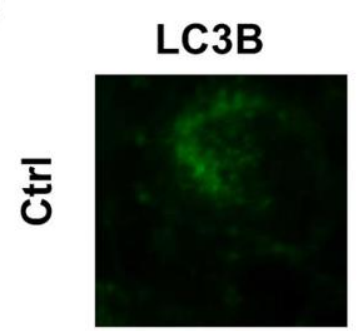

DAPI Merge
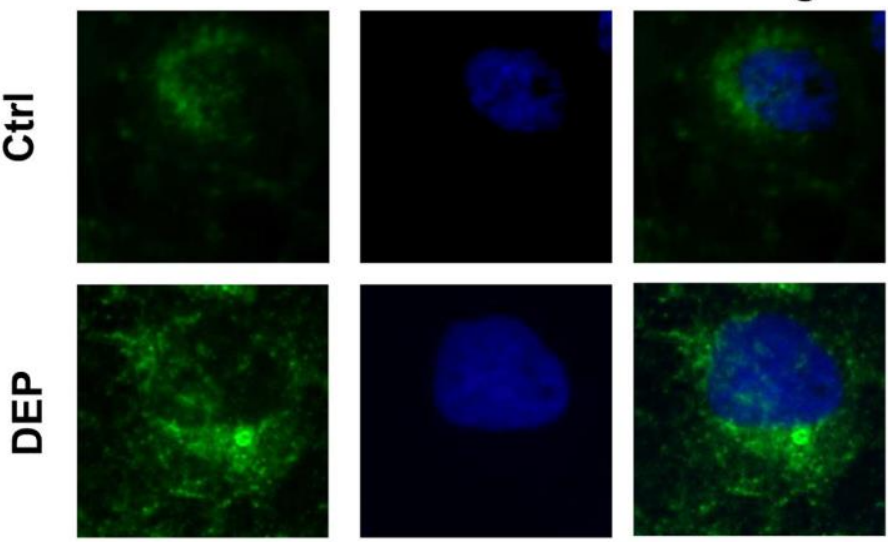

C
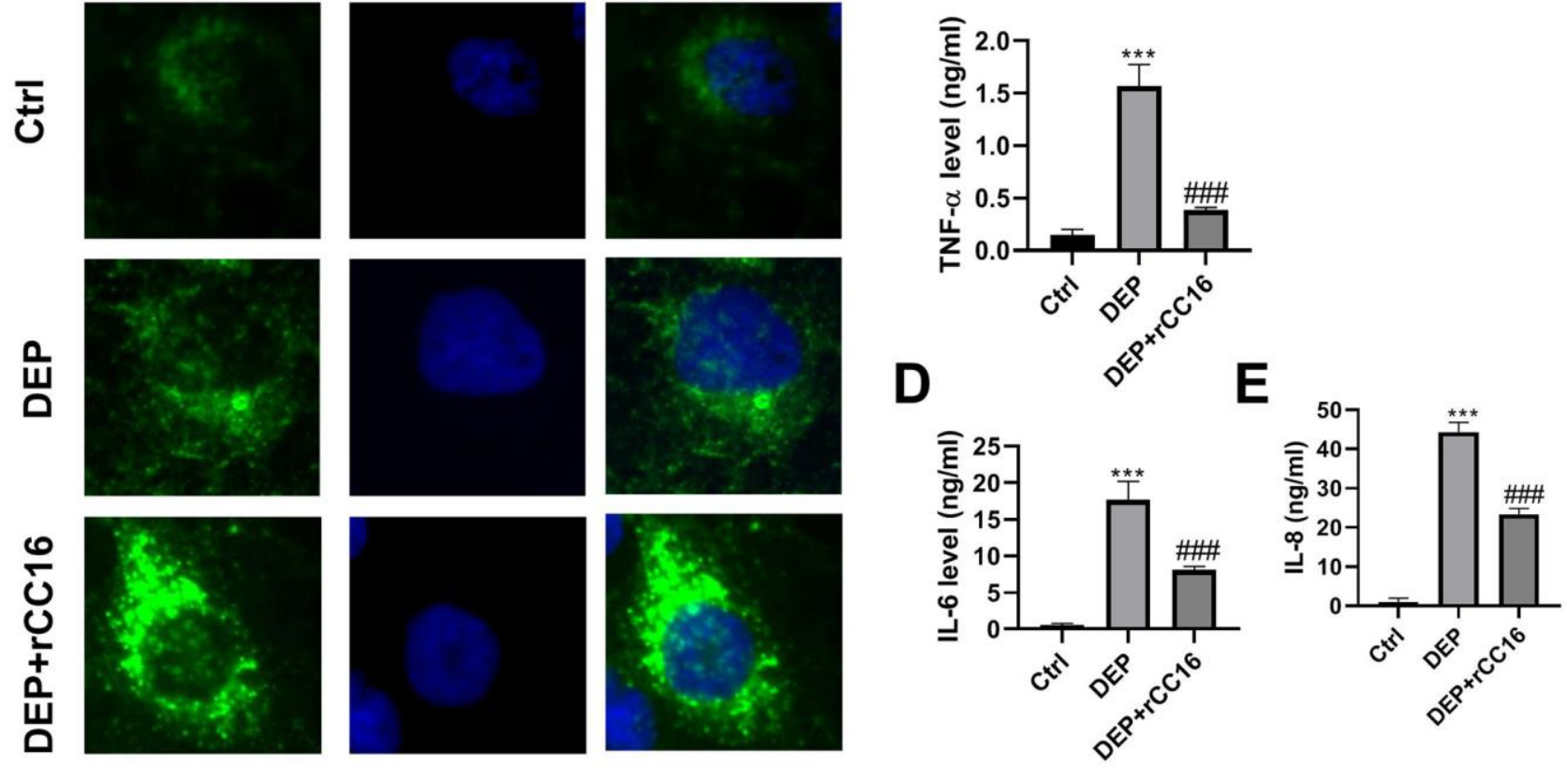

Figure 7. rCC16 relieves DEP-induced bronchial epithelial cell inflammation via activation of autophagy. BEAS-2B cells are incubated with 5 ppm SRM 1650b, or $300 \mathrm{ng} / \mathrm{ml} \mathrm{rCC16} \mathrm{+5} \mathrm{ppm} \mathrm{SRM} \mathrm{1650b} \mathrm{for} 12 \mathrm{~h}$. Then the cells and culture supernatants are harvested. (A) LC3B and p62 protein expression in BEAS-2B cells are detected by western blot. (B) Autophagy induction is evaluated by LC3B immunostaining $(\times 400)$. Autophagosomes are identified as bright green dots. (C-E) TNF- $\alpha$, IL-6, and IL- 8 level in culture supernatants are detected by ELISA. ${ }^{* * * P}<0.001$ vs. ctrl; and \#P $<0.05$ and \#\#\#P $<0.001$ vs. DEP group. 
containing DEP exposure induces IL-8 expression independently of NF- $\mathrm{KB}$ through a mechanism that requires Jun activity. In 1998, another study documented that DEP induces release of IL-6 and IL-8 by BEAS-2B cells [25]. NF- $\kappa \mathrm{B}$ and Jun are both major mediators in autophagy. Autophagy is a cellular mechanism for the sequestration and degradation of intracellular pathogens and compromised organelles, and also clears other cellular components, such as inflammasomes and pro-inflammatory cytokines. In fact, DEP has been reported to activate autophagy in BEAS-2B cells [27]. These findings tempted us to speculate that autophagy is implicated in DEP-induced inflammation. We then co-treated BEAS-2B cells with DEP exposure and the autophagy promoter Rap or autophagy inhibitor 3-MA. As we expected, we found that DEP induces autophagy and the increases of proinflammatory cytokines TNF- $\alpha$, IL- 6 , and IL- 8 level, and co-treatment with Rap or 3-MA significantly reduces or increases the level of these three proinflammatory cytokines, respectively, suggesting that enhancement of autophagy can improve DEP-induced inflammation.

The above experimental results showed that DEP inhibits CC16 secretion from Clara cells along the $\mathrm{C} / \mathrm{EBP} \alpha-M u n c 18 \mathrm{~b}$ axis, and induces the inflammatory response in BEAS-2B cells. We were curious about whether there are links between DEP-inhibited CC16 secretion in epithelial Clara cells and DEP-induced the inflammatory response in BEAS-2B airway epithelial cells without CC16 expression? Increasing evidence showed that $\mathrm{CC} 16$ protects airway epithelial cells from environmental stimuli, such as house dust mite and cigarette smoke exposure [20-22]. Herein, the role of CC16 in bronchial epithelial cells exposed to DEP was investigated. $\mathrm{CC}^{+} 6^{+}$cell conditioned media containing different concentrations of $\mathrm{CC} 16$ were prepared and used to culture BEAS-2B cells. We found a positive correlation between CC16 level and DEP-induced autophagy activity, and a negative correlation between CC16 level and DEP-induced inflammatory response, suggesting that CC16 might mitigate DEP-induced inflammation via promoting autophagy in BEAS-2B cells. We added rCC16 to BEAS-2B cells exposed to DEP, and further certified this finding. TNF- $\alpha$ has been reported as a boost to CC16 production [26]. Here, we also confirmed that DEP-induced TNF- $\alpha$ release from BEAS-2B cells stimulates $\mathrm{CC} 16$ production, suggesting that $\mathrm{CC} 16$ and TNF- $\alpha$ form a negative feedback loop.

\section{CONCLUSIONS}

Our data showed that DEP inhibits CC16 secretion from $\mathrm{CC} 16^{+}$cells via methylation of $\mathrm{C} / \mathrm{EBP} \alpha$ and inhibition of Munc18b transcription; CC16 protects against DEPinduced BEAS-2B cell inflammation via activation of autophagy; the decreased CC16 level induced by DEP exerts a weaker protective role in DEP-induced inflammation; and DEP-induced TNF- $\alpha$ release from
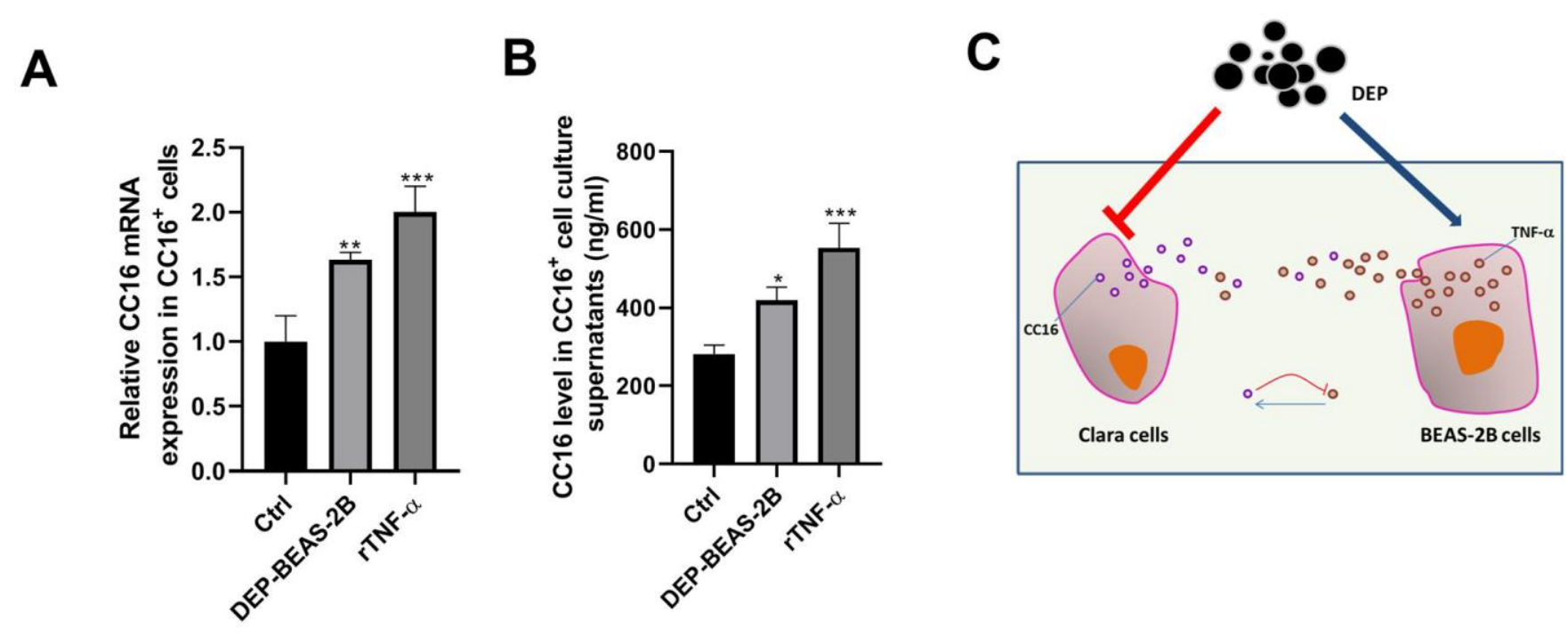

Figure 8. TNF- $\alpha$ released by BEAS-2B cells induces CC16 production and secretion from CC16 ${ }^{+}$cells. BEAS-2B cell conditioned medium (DEP-BEAS-2B) is prepared, and used to culture $\mathrm{CC}_{16}{ }^{+}$cells. The TNF- $\alpha$ level in the culture medium of ctrl, DEP-BEAS-2B, and rTNF- $\alpha$ group is $0,0.81$ and $3 \mathrm{ng} / \mathrm{ml}$, respectively. $\mathrm{CC}^{+} 6^{+}$cells are cultured in these media for $48 \mathrm{~h}$. Then CC16 mRNA expression (A) and level in culture supernatants (B) are detected by RT-PCR and ELISA assay. (C) CC16-TNF- $\alpha$ negative feedback loop between Clara cells and normal airway epithelial cells protects against DEP exposure-induced injury. Red upside down T line drawing indicates inhibitive action. Blue line with arrowhead drawing indicates driving role. $* P<0.05, * * P<0.01$ and $* * * P<0.001$ vs. Ctrl. 
BEAS-2B cells stimulates $\mathrm{CC} 16$ production and secretion in Clara cells. Our findings revealed the CC16-TNF- $\alpha$ negative feedback regulatory mechanism for protection against DEP-induced inflammation. These findings prompt us to conduct more studies for understanding the delicate regulatory mechanisms, and to investigate the potential of manipulating CC16-TNF$\alpha$ negative feedback against DEP-induced inflammation.

\section{MATERIALS AND METHODS}

\section{Preparation of single-cell suspensions from human distal lung}

All human lung tissues were obtained from patients who underwent pulmonary resection at the Qingdao Municipal Hospital. All patients provided informed consent, and the study was approved by the Qingdao Municipal Hospital Ethics Committee. Single cell suspensions of the human distal lung were prepared as previously described, with some modifications [39]. Briefly, human distant normal lung tissues were cut into small pieces, and incubated with DNase I (SigmaAldrich, St Louis, MO, USA; final concentration, 0.1 $\mathrm{mg} / \mathrm{ml}$ ), and collagenase (Roche Applied Science, Penzberg, Germany; final concentration, $3 \mathrm{mg} / \mathrm{ml}$ ) for 1 $\mathrm{h}$ at $37^{\circ} \mathrm{C}$ with continuous agitation. Following incubation with $0.25 \%$ trypsin (Sigma-Aldrich) for 10 min, the suspensions were further disaggregated by trituration through needles (Sherwood Medical Co, St Louis, MO, USA), and filtered with a $100-\mu \mathrm{m}$ mesh filter (BD Biosciences, San Jose, CA, USA). After washing with PBS, cells were treated with red blood cell lysis buffer (eBioscience, San Diego, CA, USA), filtered through a $40-\mu \mathrm{m}$ mesh filter (BD Biosciences), resuspended in DMEM/10\% fetal bovine serum (FBS; Invitrogen, Carlsbad, CA, USA) with $1 \%$ amino acid solution (Invitrogen), $2.5 \mathrm{mg} / \mathrm{ml}$ amphotericin B (Sigma-Aldrich), $100 \mathrm{U} / \mathrm{ml}$ penicillin, and $100 \mu \mathrm{g} / \mathrm{ml}$ streptomycin, and placed to recover in a humidified incubator at $37^{\circ} \mathrm{C}$ with $5 \% \mathrm{CO}_{2}$ for $24 \mathrm{~h}$.

\section{Flow cytometry}

CC16-expressing cells (Clara cells) were obtained by FACS as previously described [39]. Briefly, the recovered cells were trypsinized, and resuspended into PBS with 3\% FBS. Following incubation with an antirabbit CC16 antibody (Millipore, Billerica, MA, USA), an anti-rabbit-FITC secondary antibody was added and further incubated on ice for $30 \mathrm{~min}$. After washing in PBS with 3\% FBS, the cells were resuspended in the fresh medium. Isotype-matched rabbit IgG staining was used as a negative control, and CC16 staining with permeabilization of dissociated cells was used as a positive control. The cell fractions with minimal (CC16 fraction) and strong $\left(\mathrm{CC}^{+} 6^{+}\right.$fraction) expression of CC16 were obtained by a FACS Vantage SE cell sorter (Becton Dickinson, San Jose, CA, USA), and then examined by RT-PCR, western blot and IF.

\section{Immunofluorescence}

Cells were fixed in $4 \%$ paraformaldehyde for $10 \mathrm{~min}$ at room temperature (RT), and permeabilized with $0.1 \%$ Triton X-100 for $10 \mathrm{~min}$ at RT. After blocking with 5\% bovine serum albumin (BSA; Sigma-Aldrich) for 30 min, immunolabelling was performed via incubation of the cells with primary antibody CC16 (1:50, Santa Cruz Biotech, Santa Cruz, CA, USA), pan-keratin (1:100, Dako, Carpinteria, CA, USA), or LC3B (1:100, Cell Signaling Technology, Beverly, MA, USA) for $1 \mathrm{~h}$ in a humid chamber at RT, and subsequent incubation with secondary antibodies conjugated with Alexa Fluor 488 or 546 (Invitrogen) for $1 \mathrm{~h}$. After washing three times in PBS, slides were mounted with an anti-fading reagent with 4',6-diamidine-2-phenylindole (DAPI) (Invitrogen), air dried in the dark, and then observed under a fluorescence microscope (Olympus, Hamburg, Germany).

\section{RT-PCR}

Total RNA was extracted from the cultured cells using Trizol reagent (Invitrogen) in accordance with the instructions of the manufacturer. The cDNA synthesis was performed by using Reverse Transcription Kit (Takara, Dalian, China), and then PCR was performed on SmartCycler ${ }^{\circledR}$ II System (Cepheid Inc., Sunnyvale, CA, USA). GAPDH was used as a reference. The relative quantification of transcripts was calculated by using the $2^{-\Delta \Delta \mathrm{Ct}}$ method.

\section{Western blot analysis}

Western blot assay was conducted as previously described [40]. The primary antibodies against pankeratin (Abcam, Cambridge, MA, USA), CC16 (Millipore), C/EBP $\alpha$ (Santa Cruz Biotechnology, Santa Cruz, CA, USA), Munc18b (Abcam), LC3B (Abcam), p62 (Abcam), and GAPDH (Sigma-Aldrich), and horseradish peroxidase-conjugated secondary antibody (Abcam) were employed in this assay.

\section{ELISA}

The cells were cultured under the indicated conditions, and culture supernatants were collected used for IL-6, IL-8, TNF- $\alpha$ and CC16 level determination. The levels of the cytokines IL- 6 , IL-8, and TNF- $\alpha$ were determined by the ELISA kits purchased from Bender Medsystems (Burlingame, CA, USA), and CC16 level was detected 
by the ELISA kit obtained from BioVendor (Brno, Czech Republic).

\section{Methylation-specific polymerase chain reaction}

Genomic DNA was isolated from cultured cells using standard methods. Then DNA was modified with bisulfite by using CpGenome DNA modification kit (Intergen, Burlington, MA, USA), and then bisulfitemodified DNA (50 ng) was amplified in duplicate by MSP as described previously [41, 42]. The primer sequences for amplification were as follows: the methylated C/EBP $\alpha$, sense primer: 5'-GTCGG GTATAAAAGTTGGGTCGGC-3', and antisense primer: 5'-ATTCTCCCGACATAACGAACCTCG-3'; and unmethylated $\mathrm{C} / \mathrm{EBP} \alpha$ : sense primer: 5'-TTGTT GGGTATAAAAGTTGGGTTGGT-3', and antisense primer: 5'-AAAATTCTCCCAACATAACAAACC TCA-3'. PCR products were subsequently separated by gel electrophoresis and visualized by ethidium bromide (EB; Sigma-Aldrich) staining.

\section{$\mathrm{CC16}^{+}$cell culture and treatment}

Isolated $\mathrm{CC} 6^{+}$cells were cultured in the serum-free DMEM/F12 medium supplemented with $20 \mathrm{ng} / \mathrm{ml}$ EGF (Invitrogen), bFGF (Invitrogen) and gentamicin (SigmaAldrich), $1 \mu \mathrm{l} / \mathrm{ml}$ bovine hypothalamus extract (PromoCell, Corning, NY, USA), $5 \mu \mathrm{g} / \mathrm{ml}$ transferrin (Roche Applied Science, Indianapolis, IN, USA) and insulin (RIA, Linco Research, St. Charles, MO, USA), 1 $\mathrm{mM}$ retinol (Sigma-Aldrich) and hydrocortisone (SigmaAldrich), 1\% penicillin-streptomycin (Invitrogen), and 1 $\mathrm{ng} / \mathrm{ml}$ amphotericin B.

To assess whether DEP regulates $\mathrm{CC} 16$ production and secretion in $\mathrm{CC} 16^{+}$cells via induction of $\mathrm{C} / \mathrm{EBP} \alpha$ hypermethylation, $\mathrm{CC} 16^{+}$cells were treated with $5 \mathrm{ppm}$ SRM 1650b (the National Institute of Standards and Technology, Gaithersburg, MD, USA) in the presence of DAC (Sigma-Aldrich) or not for $48 \mathrm{~h}$. Then MSP, RT-PCR, western blot and ELISA were performed to detect the methylation of $\mathrm{C} / \mathrm{EBP} \alpha$, the mRNA and protein expression of $\mathrm{C} / \mathrm{EBP} \alpha, \mathrm{CC} 16 \mathrm{mRNA}$ expression, and CC16 level in culture supernatants, respectively. Additionally, we also determined the effects of treatment with other concentrations of SRM $1650 \mathrm{~b}(0.1,1,3$ and $10 \mathrm{ppm})$ on $\mathrm{C} / \mathrm{EBP} \alpha$ mRNA and protein expression, CC16 mRNA expression and level in culture supernatants.

To further investigate whether $\mathrm{C} / \mathrm{EBP} \alpha$ regulates the secretion of $\mathrm{CC} 16$ from $\mathrm{CC} 16^{+}$cells via Munc18b, $\mathrm{CC}_{16}{ }^{+}$cells were transfected with the specific smallinterfering RNAs targeting $\mathrm{C} / \mathrm{EBP} \alpha$ (si-C/EBP $\alpha$ ), si-Munc18b, pcDNA-C/EBP $\alpha, \quad$ pcDNA-CC16 or negative control alone or in combination using Lipofectamine 2000 (Invitrogen). The sequence fragment of $\mathrm{C} / \mathrm{EBP} \alpha$ or $\mathrm{CC} 16$ was amplified, sequenced, inserted into pcDNA3.1 vector (Invitrogen), and finally named as $\mathrm{pcDNA}-\mathrm{C} / \mathrm{EBP} \alpha$ or pcDNA-CC16. si-C/EBP $\alpha$, si-Munc18b and scrambled siRNA were synthesized by Sangon Biotechnology, Co., Ltd. (Shanghai, China). After transfection, the cells were collected used for determination of Munc18b mRNA and protein expression, and CC16 mRNA expression and secretion via RT-PCR, western blot and ELISA.

To investigate the effects of BEAS-2B cells treated with DEP on $\mathrm{CC} 16$ secretion from $\mathrm{CC} 16^{+}$cells, a BEAS-2B cell conditioned medium was prepared used for $\mathrm{CC} 16^{+}$ cell culture. In addition, to determinate whether the BEAS-2B cell conditioned medium functions via TNF$\alpha, \mathrm{CC}_{1} 6^{+}$cells were treated with human rTNF- $\alpha$ (PeproTech, Rocky Hill, NJ, USA) for 48 h. Then CC16 mRNA expression in the cells and protein level in culture supernatants were determined.

\section{Dual-luciferase reporter assay}

To investigate whether $\mathrm{C} / \mathrm{EBP} \alpha$ regulates Munc18b expression via binding to the promoter of Munc18b, the upstream regions (-2000/200) of Munc18b gene with WT or mutation of the binding motifs 1 or 2 with $\mathrm{C} / \mathrm{EBP} \alpha$ were amplified and subcloned into the pGL3Basic vector by GenePharma (Shanghai, China) to generate Munc18b promoter constructs. The cells were co-transfected with Munc18b promoter construct or empty pGL3-basic vector and $\mathrm{C} / \mathrm{EBP} \alpha$ plasmid or its corresponding empty vector. The cells were then lysed and analyzed with Dual luciferase reporter assay system (Promega, WI, USA).

\section{Preparation of $\mathrm{CC}^{+}$or BEAS-2B cell conditioned medium}

$\mathrm{CC} 16^{+}$cells were cultured in DMEM/F12 medium containing $5 \mathrm{ppm}$ SRM $1650 \mathrm{~b}$ or not for $48 \mathrm{~h}$. Then the medium was harvested, cleared by centrifugation, diluted 1:1 with F12 medium, stored at $4^{\circ} \mathrm{C}$ and named as $\mathrm{CC} 6^{+}$medium and DEP-CC $16^{+}$medium. As well, the BEAS-2B cell conditioned medium was prepared.

\section{BEAS-2B cell culture and treatment}

A human bronchial epithelial cell line BEAS-2B (American Type Culture Collection, Manassas, VA, USA) was cultured in hormonally defined Ham's F12 medium (HD-F12) supplemented with $1 \%$ penicillinstreptomycin, $5 \mu \mathrm{g} / \mathrm{ml}$ insulin and transferrin, $25 \mathrm{ng} / \mathrm{ml}$ 
EGF, $15 \mu \mathrm{g} / \mathrm{ml}$ endothelial cell growth supplement (Collaborative Research, Inc., Bedford, MA, USA), 200 pM triiodothyronine (Gibco, Carlsbad, CA, USA), and $1 \mathrm{mM}$ hydrocortisone.

To investigate whether DEP induces bronchial epithelial cell inflammation via autophagy, BEAS-2B cells were pre-treated with $1.5 \mathrm{mM} 3$-MA (Sigma-Aldrich) or 10 $\mathrm{nM}$ Rap (Sigma-Aldrich) for $1 \mathrm{~h}$, and then exposed to 5 ppm SRM 1650b for $12 \mathrm{~h}$. Western blot, IF, and ELISA were then applied to detect the autophagy-related proteins LC3B and p62 expression, and proinflammatory cytokines TNF-a, IL-6, and IL-8 level in culture supernatants.

To investigate whether $\mathrm{CC} 16$ secretion from $\mathrm{CC} 16^{+}$ cells protects against DEP-induced bronchial epithelial cell inflammation, BEAS-2B cells were divided into four groups and cultured with different medium for $12 \mathrm{~h}$, including ctrl group (equiproportional mixing of fresh DMEM/F12 and HDF12), DEP group (the same medium with ctrl group but containing 5 ppm SRM 1650b), DEP+CC16 ${ }^{+}$ group $\left(\mathrm{CC} 16^{+}\right.$medium containing $5 \mathrm{ppm}$ SRM $1650 \mathrm{~b}$ ), and DEP+DEP-CC $16^{+}$group (DEP-CC16 ${ }^{+}$ medium containing $5 \mathrm{ppm}$ SRM 1650b). Next, the expression of p62 and LC3B protein, and the levels of TNF-a, IL-6, and IL-8 level were determined by western blot, IF, and ELISA, respectively.

For further confirmation the protection role of $\mathrm{CC} 16$ against DEP-induced bronchial epithelial cell inflammation, BEAS-2B cells were exposed to $5 \mathrm{ppm}$ SRM 1650b in the presence of rCC16 (prepared by our laboratory) or not for $12 \mathrm{~h}$. Then autophagy and inflammation were determined.

\section{Chromatin immunoprecipitation}

ChIP assay was conducted by using a ChIP assay Kit (Upstate Biotechnology, Billerica, MA, USA) as per the manufacturer's instructions. Briefly, the cells were harvested, fixed with $1 \%$ formaldehyde for $10 \mathrm{~min}$ at RT, and resuspended in lysis buffer containing a protease inhibitor cocktail. Following sonication, the soluble chromatin was diluted with ChIP-dilution buffer and immunoprecipitated with $\mathrm{C} / \mathrm{EBP} \alpha$ antibody or IgG as a negative control overnight at $4^{\circ} \mathrm{C}$. Then the chromatin-antibody complexes were eluted with the elution buffer. After reversion of the cross-link, the DNA was purified by Qiaquick PCR product Purification Kit (QIAGEN Inc, Chatsworth, CA, USA). End-point PCR was conducted to amplify the site 1 and 2 (two potential binding motifs for $\mathrm{C} / \mathrm{EBP} \alpha$ ) by using primers spanning the $\mathrm{C} / \mathrm{EBP} \alpha$ binding elements in the promoter region of the Munc18b gene.

\section{Statistical analysis}

All statistical analyses were performed with GraphPad Prism 8. The data were presented as the mean \pm standard deviation (SD) from at least three independent experiments. The comparisons between groups were done using the Student's $t$ test or ANOVA, and $P<0.05$ was considered to be statistically significant.

\section{AUTHOR CONTRIBUTIONS}

Wei Han and Wanming Hao designed this work. Ting $\mathrm{Hu}$ performed the most experiments and drafted the manuscript. Fenglan Sun and Xinjuan Yu performed IF assay and analyzed the data. Qinghai Li and Long Zhao plotted the figures. All authors read and approved the final manuscript.

\section{CONFLICTS OF INTEREST}

The authors declare that they have no conflicts of interest.

\section{FUNDING}

This work was supported by National Natural Science Foundation of China (grant No. 81973012).

\section{Editorial note}

${ }^{\&}$ This corresponding author has a verified history of publications using a personal email address for correspondence.

\section{REFERENCES}

1. Hasunuma H, Ishimaru $Y$, Yoda $Y$, Shima M. Decline of ambient air pollution levels due to measures to control automobile emissions and effects on the prevalence of respiratory and allergic disorders among children in Japan. Environ Res. 2014; 131:111-18. https://doi.org/10.1016/j.envres.2014.03.007 PMID:24727639

2. D'Amato G, Holgate ST, Pawankar R, Ledford DK, Cecchi L, Al-Ahmad M, Al-Enezi F, Al-Muhsen S, Ansotegui I, Baena-Cagnani CE, Baker DJ, Bayram H, Bergmann KC, et al. Meteorological conditions, climate change, new emerging factors, and asthma and related allergic disorders. A statement of the World Allergy Organization. World Allergy Organ J. 2015; 8:25. https://doi.org/10.1186/s40413-015-0073-0 PMID:26207160

3. Du Y, Xu X, Chu M, Guo Y, Wang J. Air particulate matter and cardiovascular disease: the 
epidemiological, biomedical and clinical evidence. J Thorac Dis. 2016; 8:E8-19.

https://doi.org/10.3978/j.issn.2072-1439.2015.11.37 PMID:26904258

4. Chan TC, Zhang Z, Lin BC, Lin C, Deng HB, Chuang YC, Chan JW, Jiang WK, Tam T, Chang LY, Hoek G, Lau AK, Lao XQ. Long-Term Exposure to Ambient Fine Particulate Matter and Chronic Kidney Disease: A Cohort Study. Environ Health Perspect. 2018; 126:107002.

https://doi.org/10.1289/EHP3304

PMID:30392394

5. Apte JS, Marshall JD, Cohen AJ, Brauer M. Addressing Global Mortality from Ambient PM2.5. Environ Sci Technol. 2015; 49:8057-66.

https://doi.org/10.1021/acs.est.5b01236 PMID:26077815

6. Franklin M, Koutrakis P, Schwartz P. The role of particle composition on the association between PM2.5 and mortality. Epidemiology. 2008; 19:680-89.

https://doi.org/10.1097/ede.0b013e3181812bb7 PMID: 18714438

7. Liu J, Ye X, Ji D, Zhou X, Qiu C, Liu W, Yu L. Diesel exhaust inhalation exposure induces pulmonary arterial hypertension in mice. Environ Pollut. 2018; 237:747-55.

https://doi.org/10.1016/j.envpol.2017.10.121 PMID:29137886

8. Bayram H, Devalia JL, Khair OA, Abdelaziz MM, Sapsford RJ, Sagai M, Davies RJ. Comparison of ciliary activity and inflammatory mediator release from bronchial epithelial cells of nonatopic nonasthmatic subjects and atopic asthmatic patients and the effect of diesel exhaust particles in vitro. J Allergy Clin Immunol. 1998; 102:771-82.

https://doi.org/10.1016/s0091-6749(98)70017-x PMID: 9819294

9. Hart JE, Laden F, Schenker MB, Garshick E. Chronic obstructive pulmonary disease mortality in dieselexposed railroad workers. Environ Health Perspect. 2006; 114:1013-17. https://doi.org/10.1289/ehp.8743 PMID:16835052

10. Wang $N$, Li $Q$, Liu H, Lin L, Han W, Hao W. Role of $\mathrm{C} / \mathrm{EBP} \alpha$ hypermethylation in diesel engine exhaust exposure-induced lung inflammation. Ecotoxicol Environ Saf. 2019; 183:109500.

https://doi.org/10.1016/j.ecoenv.2019.109500 PMID:31450033

11. Hao W, Wang J, Zhang Y, Wang Y, Sun L, Han W. Leptin positively regulates MUC5AC production and secretion induced by interleukin-13 in human bronchial epithelial cells. Biochem Biophys Res Commun. 2017; 493:979-84.

https://doi.org/10.1016/j.bbrc.2017.09.106

PMID:28942146

12. Su Y, Wang J, Zou J, Han W, Li S. miR-330 regulates interleukin-13-induced MUC5AC secretion by targeting Munc18b in human bronchial epithelial cells. Int J Clin Exp Pathol. 2018; 11:3463-70.

PMID:31949724

13. Bernard A, Marchandise FX, Depelchin S, Lauwerys R, Sibille Y. Clara cell protein in serum and bronchoalveolar lavage. Eur Respir J. 1992; 5:1231-38. PMID: 1486970

14. Johnson MD, Younis US, Menghani SV, Addison KJ, Whalen $\mathrm{M}$, Pilon AL, Cress AE, Polverino F, Romanoski CE, Kraft M, Martinez FD, Guerra S, Ledford JG. CC16 Binding to $\alpha_{4} \beta_{1}$ Integrin Protects against Mycoplasma pneumoniae Infection. Am J Respir Crit Care Med. 2021; 203:1410-18.

https://doi.org/10.1164/rccm.202006-25760C PMID:33326355

15. Vollrath JT, Stoermann P, Becker N, Wutzler S, Hildebrand F, Marzi I, Relja B. Early local neutralization of CC16 in sepsis-induced ALI following blunt chest trauma leads to delayed mortality without benefitting overall survival. Int J Mol Med. 2020; 46:2207-15. https://doi.org/10.3892/ijmm.2020.4767 PMID:33125155

16. Zhou R, Qu Y, Huang Q, Sun X, Mu D, Li X. Recombinant CC16 regulates inflammation, oxidative stress, apoptosis and autophagy via the inhibition of the p38MAPK signaling pathway in the brain of neonatal rats with sepsis. Brain Res. 2019; 1725:146473.

https://doi.org/10.1016/i.brainres.2019.146473 PMID:31557475

17. Störmann P, Becker N, Vollrath JT, Köhler K, Janicova A, Wutzler S, Hildebrand F, Marzi I, Relja B. Early Local Inhibition of Club Cell Protein 16 Following Chest Trauma Reduces Late Sepsis-Induced Acute Lung Injury. J Clin Med. 2019; 8:896.

https://doi.org/10.3390/jcm8060896

PMID:31234556

18. Lin J, Li J, Shu M, Wu W, Zhang W, Dou Q, Wu J, Zeng X. The rCC16 Protein Protects Against LPS-Induced Cell Apoptosis and Inflammatory Responses in Human Lung Pneumocytes. Front Pharmacol. 2020; 11:1060.

https://doi.org/10.3389/fphar.2020.01060 PMID: $\underline{32760279}$

19. Becker N, Störmann P, Janicova A, Köhler K, Horst K, Dunay IR, Neunaber C, Marzi I, Vollrath JT, Relja B. Club Cell Protein 16 Attenuates $\mathrm{CD} 16{ }^{\text {bright }} \mathrm{CD} 62^{\text {dim }}$ Immunosuppressive Neutrophils in Damaged Tissue 
upon Posttraumatic Sepsis-Induced Lung Injury. J Immunol Res. 2021; 2021:6647753.

https://doi.org/10.1155/2021/6647753

PMID:33575362

20. Liu M, Lu J, Zhang Q, Zhang Y, Guo Z. Clara cell 16 $\mathrm{KDa}$ protein mitigates house dust mite-induced airway inflammation and damage via regulating airway epithelial cell apoptosis in a manner dependent on HMGB1-mediated signaling inhibition. Mol Med. 2021; 27:11.

https://doi.org/10.1186/s10020-021-00277-4

PMID:33541260

21. Lam DC, Kwok HH, Yu WC, Ko FW, Tam CY, Lau AC, Fong DY, Ip MS. CC16 levels correlate with cigarette smoke exposure in bronchial epithelial cells and with lung function decline in smokers. BMC Pulm Med. 2018; $18: 47$.

https://doi.org/10.1186/s12890-018-0607-7

PMID:29548305

22. Laing IA. CC16: A Biomarker of Pollutant Exposure and Future Lung Disease? Am J Respir Crit Care Med. 2019; 200:529-30.

https://doi.org/10.1164/rccm.201903-0559ED PMID:30917285

23. Takizawa H, Ohtoshi T, Kawasaki S, Kohyama T, Desaki M, Kasama T, Kobayashi K, Nakahara K, Yamamoto K, Matsushima K, Kudoh S. Diesel exhaust particles induce NF-kappa B activation in human bronchial epithelial cells in vitro: importance in cytokine transcription. J Immunol. 1999; 162:4705-11.

PMID:10202011

24. Tal TL, Simmons SO, Silbajoris R, Dailey L, Cho SH, Ramabhadran R, Linak W, Reed W, Bromberg PA, Samet JM. Differential transcriptional regulation of IL-8 expression by human airway epithelial cells exposed to diesel exhaust particles. Toxicol Appl Pharmacol. 2010; 243:46-54.

https://doi.org/10.1016/j.taap.2009.11.011

PMID:19914270

25. Steerenberg PA, Zonnenberg JA, Dormans JA, Joon PN, Wouters IM, van Bree L, Scheepers PT, Van Loveren $\mathrm{H}$. Diesel exhaust particles induced release of interleukin 6 and 8 by (primed) human bronchial epithelial cells (BEAS 2B) in vitro. Exp Lung Res. 1998; 24:85-100.

https://doi.org/10.3109/01902149809046056 PMID: $\underline{9457471}$

26. Yao XL, Levine SJ, Cowan MJ, Logun C, Shelhamer JH. Tumor necrosis factor-alpha stimulates human Clara cell secretory protein production by human airway epithelial cells. Am J Respir Cell Mol Biol. 1998; 19:629-35.

https://doi.org/10.1165/ajrcmb.19.4.3129
PMID: $\underline{9761760}$

27. Frias DP, Gomes RL, Yoshizaki K, Carvalho-Oliveira $R$, Matsuda $M$, Junqueira MS, Teodoro WR, Vasconcellos PC, Pereira DC, Conceição PR, Saldiva $\mathrm{PH}$, Mauad T, Macchione M. Nrf2 positively regulates autophagy antioxidant response in human bronchial epithelial cells exposed to diesel exhaust particles. Sci Rep. 2020; 10:3704. https://doi.org/10.1038/s41598-020-59930-3 PMID:32111854

28. Totlandsdal Al, Cassee FR, Schwarze P, Refsnes M, Låg M. Diesel exhaust particles induce CYP1A1 and proinflammatory responses via differential pathways in human bronchial epithelial cells. Part Fibre Toxicol. 2010; 7:41.

https://doi.org/10.1186/1743-8977-7-41 PMID:21162728

29. Li YJ, Shimizu T, Hirata $Y$, Inagaki H, Takizawa $H$, Azuma A, Kawada T, Sugawara I, Kudoh S, Sunazuka T, Omura S. EM, EM703 inhibit NF-kB activation induced by oxidative stress from diesel exhaust particle in human bronchial epithelial cells: importance in IL-8 transcription. Pulm Pharmacol Ther. 2013; 26:318-24.

https://doi.org/10.1016/i.pupt.2012.12.010 PMID:23291319

30. Bayram H, Fakili F, Gögebakan B, Bayraktar R, Oztuzcu $S$, Dikensoy O, Chung KF. Effect of serum on diesel exhaust particles (DEP)-induced apoptosis of airway epithelial cells in vitro. Toxicol Lett. 2013; 218:215-23. https://doi.org/10.1016/j.toxlet.2013.02.006 PMID:23454527

31. Perić A, Mirković CŠ, Vojvodić D. Clara cell protein 16 release from the nasal mucosa in allergic rhinitis, chronic rhinosinusitis, and exposure to air pollutants. Arh Hig Rada Toksikol. 2018; 69:215-19. https://doi.org/10.2478/aiht-2018-69-3081 PMID:30285942

32. Lomas DA, Silverman EK, Edwards LD, Miller BE, Coxson $\mathrm{HO}$, Tal-Singer $\mathrm{R}$, and Evaluation of COPD Longitudinally to Identify Predictive Surrogate Endpoints (ECLIPSE) investigators. Evaluation of serum CC-16 as a biomarker for COPD in the ECLIPSE cohort. Thorax. 2008; 63:1058-63.

https://doi.org/10.1136/thx.2008.102574 PMID: 18757456

33. Rong B, Fu T, Gao W, Li M, Rong C, Liu W, Liu H. Reduced Serum Concentration of CC16 Is Associated with Severity of Chronic Obstructive Pulmonary Disease and Contributes to the Diagnosis and Assessment of the Disease. Int J Chron Obstruct Pulmon Dis. 2020; 15:461-70.

https://doi.org/10.2147/COPD.S230323 
PMID: $\underline{32184583}$

34. Wang SZ, Rosenberger CL, Espindola TM, Barrett EG, Tesfaigzi Y, Bice DE, Harrod KS. CCSP modulates airway dysfunction and host responses in an Ova-challenged mouse model. Am J Physiol Lung Cell Mol Physiol. 2001; 281:L1303-11.

https://doi.org/10.1152/ajplung.2001.281.5.L1303 PMID:11597923

35. Zhai J, Insel M, Addison KJ, Stern DA, Pederson W, Dy A, Rojas-Quintero J, Owen CA, Sherrill DL, Morgan W, Wright AL, Halonen M, Martinez FD, et al. Club Cell Secretory Protein Deficiency Leads to Altered Lung Function. Am J Respir Crit Care Med. 2019; 199:302-12.

https://doi.org/10.1164/rccm.201807-13450C PMID:30543455

36. Zhang S, Jia Q, Song J, Tan Q, Yu G, Guo X, Zhang H. Clinical significance of CC16 and IL-12 in bronchoalveolar lavage fluid of various stages of silicosis. Ann Palliat Med. 2020; 9:3848-56.

https://doi.org/10.21037/apm-20-1838 PMID:33302652

37. Almuntashiri S, Zhu Y, Han Y, Wang X, Somanath PR, Zhang D. Club Cell Secreted Protein CC16: Potential Applications in Prognosis and Therapy for Pulmonary Diseases. J Clin Med. 2020; 9:4039. https://doi.org/10.3390/jcm9124039 PMID:33327505

38. Aksoy MO, Li X, Borenstein M, Yi Y, Kelsen SG. Effects of topical corticosteroids on inflammatory mediatorinduced eicosanoid release by human airway epithelial cells. J Allergy Clin Immunol. 1999; 103:1081-91. https://doi.org/10.1016/s0091-6749(99)70183-1 PMID:10359890
39. Wang $X Y$, Keefe KM, Jensen-Taubman SM, Yang D, Yan $\mathrm{K}$, Linnoila RI. Novel method for isolation of murine clara cell secretory protein-expressing cells with traces of stemness. PLoS One. 2012; 7:e43008.

https://doi.org/10.1371/journal.pone.0043008 PMID:22916196

40. Schmidt LH, Spieker T, Koschmieder S, Schäffers S, Humberg J, Jungen D, Bulk E, Hascher A, Wittmer D, Marra A, Hillejan L, Wiebe K, Berdel WE, et al. The long noncoding MALAT-1 RNA indicates a poor prognosis in non-small cell lung cancer and induces migration and tumor growth. J Thorac Oncol. 2011; 6:1984-92. https://doi.org/10.1097/JTO.0b013e3182307eac PMID:22088988

41. Herman JG, Graff JR, Myöhänen S, Nelkin BD, Baylin SB. Methylation-specific PCR: a novel PCR assay for methylation status of $\mathrm{CpG}$ islands. Proc Natl Acad Sci USA. 1996; 93:9821-26.

https://doi.org/10.1073/pnas.93.18.9821

PMID:8790415

42. Campbell BC, Mitchell PJ, Kleinig TJ, Dewey HM, Churilov L, Yassi N, Yan B, Dowling RJ, Parsons MW, Oxley TJ, Wu TY, Brooks M, Simpson MA, et al, and EXTEND-IA Investigators. Endovascular therapy for ischemic stroke with perfusion-imaging selection. N Engl J Med. 2015; 372:1009-18.

https://doi.org/10.1056/NEJMoa1414792

PMID:25671797 